Int. J. Dev. Biol. 53: 1515-1528 (2009)

doi: $10.1387 / \mathrm{ijdb} .072446 \mathrm{av}$

\title{
Early neural cell death: numbers and cues from the developing neuroretina
}

\author{
ANA I. VALENCIANO ${ }^{1,2}$, PATRICIA BOYA ${ }^{1}$ and ENRIQUE J. DE LA ROSA ${ }^{1, *}$ \\ ${ }^{1} 3 D$ Lab (Development, Differentiation \& Degeneration), Department of Cellular and Molecular Physiopathology, \\ Centro de Investigaciones Biológicas, CSIC and \\ ${ }^{2}$ Departamento de Fisiología Animal II, Facultad de Ciencias Biológicas, Universidad Complutense de Madrid, Spain
}

\begin{abstract}
Programmed cell death is a well established key process required for proper development of the nervous system. The regulatory and executor mechanisms controlling survival/ death of projection neurons, as well as of other types of differentiated neurons and glial cells, have been studied intensely during neural development. Much less attention has been paid to earlier cell death events affecting neuroepithelial cells and recently born neurons and glial cells. We review here the reports on cell death during vertebrate retina development, our model system for many years, which has provided clear evidence of the importance of early neural cell death. We tentatively categorize the available observations in three death phases, namely morphogenetic cell death, early neural cell death and neurotrophic cell death. The magnitude and the precise regulation of the early phases of cell death are fully comparable to the much better characterized neurotrophic cell death. Therefore, early neural cell death deserves a profound dedicated study; this will help to obtain an integrated understanding of the development of the retina and other parts of the vertebrate nervous system.
\end{abstract}

KEY WORDS: apoptosis, neural development, proliferation, differentiation, neurogenesis

The nervous system contains an amazingly complex array of cell types and stereotypic connections that form the basis of its sophisticated functionality. The studies of Santiago Ramón y Cajal revealed many aspects of the intricate neuronal layout of the nervous system in detailed microscopic preparations and beautiful drawings (Fig. 1). However, one century later neuroscientists still fail to fully understand just how such diversity and complexity is achieved.

Most of the nervous system arises from apparently undifferentiated neuroepithelial cells that are in a state of proliferation. These neuroepithelial cells undergo a developmental process that takes them through the sequentially stages of neural stem cells, neural progenitors, neuroblasts or glioblasts, until they finally become differentiated neurons or glial cells. Thus, proliferation and differentiation, as well as cell migration, axonal and dendritic growth and navigation, have been clearly recognized as fundamental processes in generating neural complexity and, consequently, these processes have been studied intensely during neural development. As elaborated in the neurotrophic theory, another particu- larly relevant process in refining neural morphology and physiology is that of programmed cell death (PCD), which affects projecting neurons as well as other types of differentiated neurons and glia (Kuan etal., 2000; Roth and D'Sa, 2001; Davies, 2003; Buss etal., 2006).

However, this is neither the only nor the earliest cell death that occurs in the developing nervous system. Neural stem cells, proliferating progenitors, and recently born neurons and glia are all also affected by cell death (de la Rosa and de Pablo, 2000; Yeo and Gautier, 2004; Boya and de la Rosa, 2005). Although this early phase of neural cell death is increasingly being studied, the cell populations affected, the regulatory mechanisms involved, its magnitude and the functional implications of this process are still

Abbreviations used in this paper: AC, amacrine cell; BC, bipolar cell; E, day of embryonic development; GCL, ganglion cell layer; INL, inner nuclear layer; MC, Müller glial cell; NBL, neuroblastic layer; ONL, outer nuclear layer; P, postnatal day; PCD, programmed cell death; PhR, photoreceptor; RGC, retinal ganglion cell; TUNEL, TdT-mediated dUTP nick end labelling.

\footnotetext{
*Address correspondence to: Enrique J. de la Rosa. Centro de Investigaciones Biológicas, CSIC, C/ Ramiro de Maeztu 9, 28040 Madrid, Spain. Fax: +34-91-536-0432. e-mail: ejdelarosa@cib.csic.es
}

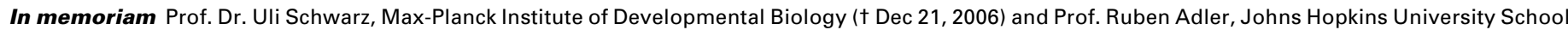
of Medicine († Dec 31, 2007).

Final author-corrected PDF published online: 17th April 2008.

ISSN: Online 1696-3547, Print 0214-6282

(c) 2008 UBC Press

Printed in Spain 
far from being appropriately characterized. This limited understanding of early neural cell death may be impeding an integrated understanding of neural development.

The vertebrate neuroretina is one of the classic model systems used in developmental neurobiology (Cepko et al., 1996; Harris, 1997; Marquardt and Gruss, 2002; Adler, 2005). The retina is an accessible part of the central nervous system since it is located outside of the brain and it can be subjected to a variety of experimental approaches, including in vivo manipulation using classic experimental embryological techniques, particularly in nonmammalian vertebrates. Several reviews have addressed early neural cell death as a global process in the developing nervous system, including those referred to above. Here we will focus on the retina, our model system for many years, which has provided clear evidence of the importance of early neural cell death.

\section{Retinal development is affected by several phases of cell death}

Retinal development commences with the induction of the retinal anlage in the neural plate/neural tube, the morphogenesis of the optic vesicle and optic cup, and it proceeds with the proliferation of the neuroepithelial cells, the generation of differentiated neurons and glia, the migration to their proper retinal layer, axon and dendrite growth and navigation, synaptogenesis and functional refinement (Cepko et al., 1996; Chow and Lang, 2001; Levine and Green, 2004; Harada et al., 2007; Lamb et al., 2007). PCD occurs simultaneously to these processes and it can be considered a genuine developmental process. Numerous events of cell death have been independently characterized in several vertebrate species (Tables 1-6, and reviewed in Cellerino et al., 2000; Vecino et al., 2004; Farah, 2006; Guerin et al., 2006), although such studies have more commonly focused on later periods of retinal development. However, by simply considering their timing, many of these studies highlight that most if not all of the aforementioned developmental processes in the retina are af-
TABLE 1

\section{VERTEBRATE SPECIES REFERRED TO IN THIS REVIEW}

\begin{tabular}{ll} 
Common name & Scientific name \\
\hline Zebrafish & Danio rerio \\
Medaka & Oryzias latipes \\
African cichlid fish & Haplochromis burtoni \\
Brown trout & Salmo trutta \\
Grass frog & Rana temporaria \\
Clawed frog & Xenopus laevis \\
Turtle & Mauremys leprosa \\
Chick & Gallus domesticus \\
Quail & Coturnix coturnix \\
Wallaby & Setonix brachyurus \\
Cat & Felix catus \\
Ferret & Mustela putorius furo \\
Rabbit & Oryctolagus cuniculus \\
Mouse & Mus musculus \\
Rat & Rattus norvergicus \\
Hamster & Mesocricetus auratus \\
Guinea pig & Cavia porcellus \\
Rhesus monkey & Macaca mulatta \\
Human & Homo sapiens \\
\hline
\end{tabular}

Common and scientific names are referred to for identification.

fected by PCD, a fact not well recognized in the literature. Here, we review the observations made on $P C D$ in the vertebrate retina, which we have tentatively organized according to the developmental phases in which they occur, denominated: morphogenic cell death (programmed cell death related with optic vesicle evagination, optic cup invagination and closure of the optic fissure); early neural cell death (programmed cell death affecting proliferating neuroepithelial cells and recently born neurons and glia); and neurotrophic cell death (programmed cell death affecting differentiated neurons mostly due to lack of neurotrophic support or inappropriate synaptogenesis).

Before addressing these issues, we should first recall several facts that hinder precise comparison and temporal compartmentalization of cell death during retinal development. The development of the retina occurs along prominent spatio-temporal gradients

TABLE 2

MORPHOGENIC CELL DEATH IN RETINAL DEVELOPMENT

\begin{tabular}{|c|c|c|c|}
\hline Species & $\begin{array}{l}\text { Developmental stage } \\
\text { range \& (peak) }\end{array}$ & Process, distribution \& magnitude & References \\
\hline Zebrafish & Hpf 12-18 (Hpf 16) & $\begin{array}{l}\text { Invagination of the optic vesicle. } 20 \text { apoptotic cells per retina. } 0.9 \% \text { of neuroepithelial cells dying at } \\
\text { Hpf } 16 .\end{array}$ & $\begin{array}{l}\text { Li et al., } 2000 \\
\text { Cole and Ross, } 2001\end{array}$ \\
\hline Medaka & $\begin{array}{l}\text { Stg } 20-26 \\
\text { (Stg 24-26) }\end{array}$ & PCD in the neuroepithelium. & lijima and Yokohama, 2007 \\
\hline Brown trout & $5-8 \mathrm{~mm}(5 \mathrm{~mm})$ & $\begin{array}{l}\text { Morphogenesis of the optic vesicle and cup. Proliferating cells dying in the neuroepithelium. } 500 \\
\text { apoptotic cells } / \mathrm{mm}^{2} \text { at } 5 \mathrm{~mm} \text {. Cell death decreases just after the formation of the optic cup. }\end{array}$ & Candal et al., 2005 \\
\hline Grass frog & Hpf 25-48 & Invagination of the optic vesicle. Proliferating cells dying in the central retina. & Glücksmann, 1940 \\
\hline Clawed frog & Stg 26-32 & Invagination of the optic vesicle and closure of the optic fissure. & Hensey and Gautier, 1998 \\
\hline Chick & $\mathrm{HH} 12-17(\mathrm{HH} 15)$ & Formation of the optic cup. PCD in the optic fissure. 1515 pyknotic fragments at HH15. & $\begin{array}{l}\text { Martín-Partido et al., } 1988 \\
\text { Trousse et al., } 2001 \text { Valenciano et al., } 2002\end{array}$ \\
\hline Ferret & E20 & Cell death in the optic fissure before its closing. & Strongin and Guillery, 1981 \\
\hline Mouse & $\mathrm{E} 10.5-14.5(\mathrm{E} 10.5)$ & $\begin{array}{l}\text { PCD in the neuroepithelium. Closure of the optic fissure. } 2 \% \text { of neuroepithelial cells dying in central } \\
\text { retina at E10.5. }\end{array}$ & $\begin{array}{l}\text { Strongin and Guillery, } 1981 \\
\text { Laemle et al., } 1999 \\
\text { Van Kefflens et al., } 1999 \\
\text { Ozeki et al., } 2000 \\
\text { Trousse et al., } 2001 \\
\text { Péquignot et al., } 2003 \\
\text { Rodríguez-Gallardo et al. } 2005\end{array}$ \\
\hline Rat & E13 & Cell death in the optic fissure. & Kuwabara and Weidman, 1974 \\
\hline Hamster & E10 & Cell death in the optic fissure before its closing. & Strongin and Guillery, 1981 \\
\hline Human & ND & Cell death in the optic fissure before its closing. & Strongin and Guillery, 1981 \\
\hline
\end{tabular}

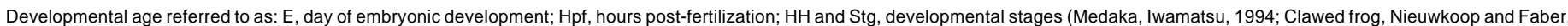
1967; Chick, Hamburger and Hamilton, 1951); mm, length of the embryo; ND, not determined. Abbreviations: PCD, programmed cell death. 


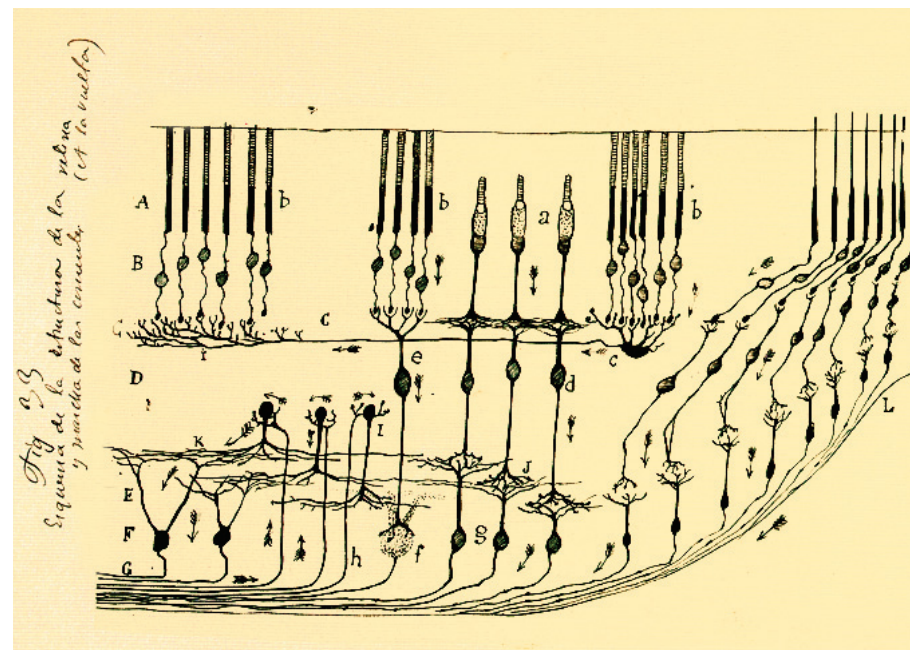

Fig. 1 (Left). Schematic representation of the structure of the mammalian retina. Artistic grouping of cells and the direction of "current flow" as depicted by Santiago Ramón y Cajal (1901). (A) Layer of rods and cones; (B) visual cell body layer; (C) outer plexiform layer; (D) bipolar cell layer; (E) inner plexiform layer; (F) layer of ganglion cells; (G) optic nerve fiber layer; (L) central fossa. Reproduced from the original drawing deposited at the Cajal Institute, CSIC, Madrid, Spain with permission.
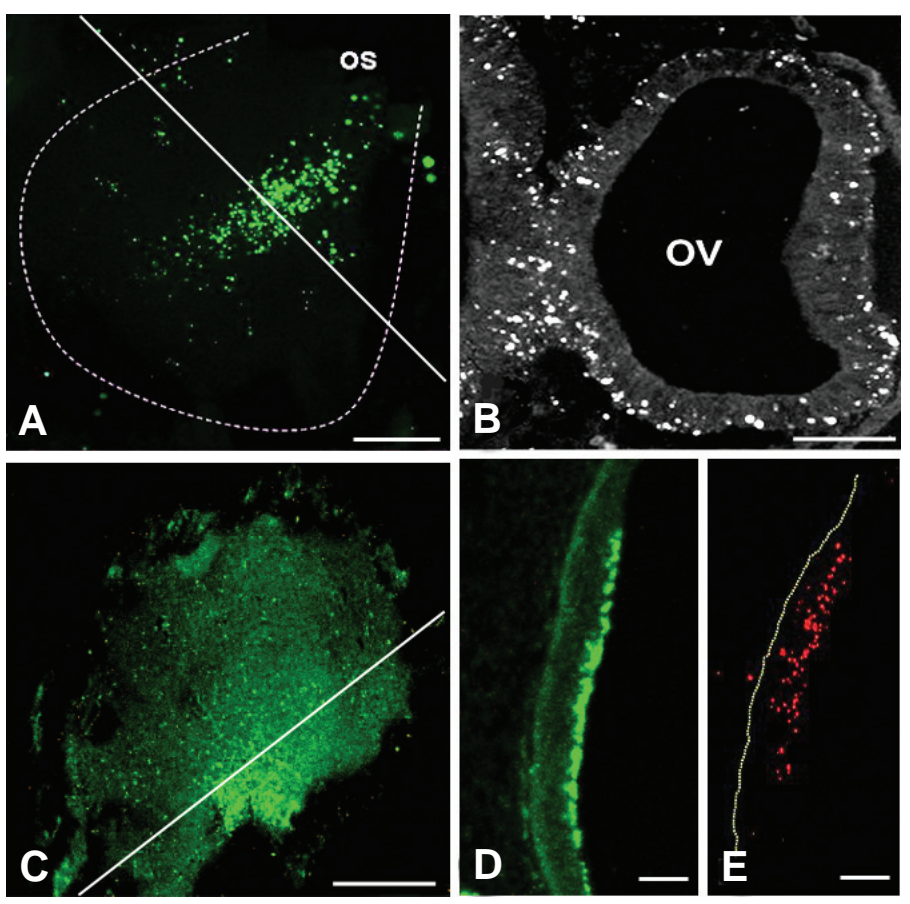

Fig. 2 (Right). Spatiotemporal correlation of proliferation, retinal ganglion cell neurogenesis and cell death. (A) Distribution of dying cells in the HH16-17 chick retina, as visualized by TUNEL staining of a whole-mount retina. The profile of the neuroretina is marked by a dashed line. The continuous line indicates the approximate plane of the section showed in (B) (reproduced from Valenciano et al., 2002). (B) Distribution of proliferating cells in the HH16 chick retina, as visualized by BrdU incorporation and immunostaining of a retinal section (reproduced from Mayordomo et al., 2003). Note that TUNEL-positive nuclei ((A), green) are concentrated in the presumptive optic fissure whereas BrdU-positive nuclei (B, white) appear to be scattered throughout the whole retina. (C) Distribution of dying cells in the E4 chick retina, as visualized by TUNEL staining of a whole-mount retina. The continuous line indicates the approximate plane of the sections showed in (D,E) (reproduced from Díaz et al., 1999). (D) Distribution of retinal ganglion cells in the E4 chick retina, as visualized by Islet 1/2 immunostaining in a retinal section (reproduced from Díaz et al., 2000 ). (E) Distribution of dying cells in the E4 chick retina, as visualized by TUNEL of a retinal section adjacent to that shown in (D) (reproduced from Díaz et al., 2000). Note that TUNEL-positive nuclei ((C) green; (E) red) and RGC, Islet 1/2-positive nuclei ((D) green) are located in overlapping areas of the central retina. The dotted line indicates the outer margin of the retina. Scale bar: $200 \mu \mathrm{m}$ in (A), $75 \mu \mathrm{m}$ in (B), (D) and (E), $1 \mathrm{~mm}$ in (C). Images reproduced with permission from $(A)$ Lippincott, Williams \& Wilkins, $(B, C)$ European Neuroscience Association and $(D, E)$ The Company of Biologists.

implying that cells at different locations of the same retina may be involved in different developmental processes. Moreover, in lower vertebrates there is indefinite growth of the retina and hence, its initial development is significantly accelerated which results in an overlap of the phases of cell death defined above. In the various vertebrate groups, differences are evident in the cellular composition and developmental timing of the retina often making direct comparisons difficult. Furthermore, in the studies carried out to date, comparisons of cell death have been hindered by the many different methods employed: from electron microscopy in tissue sections to TdT-mediated dUTP nick end labelling (TUNEL) analysis of whole-mount retinas. Similarly, both absolute (total and cumulative numbers) and relative (cell densities and actual numbers) quantification may or may not have been performed. Besides that, cumulative numbers of dead cells are not directly extrapolable from actual numbers at a defined time because apoptotic cells are efficiently removed from the tissue. Thus, we present here a tentative analysis of the descriptive data available from different vertebrate groups, as well as the quantitative information where available, attempting to organize them in relation to the distinct phases of PCD that occur throughout retinal development.

\section{Morphogenic cell death during eye development}

Several studies have focused on PCD during the initial stages of eye and retinal development, including during eye morphogenesis and in the early stages of proliferation within the retinal neuroepithelium (Table 2 and references herein). At these stages, the dying cells are selectively associated to the developing optic fissure (Fig. 2A), probably in correlation with the ongoing morphogenesis. It has been suggested that this death is involved in sculpting the retina and facilitating the exit of optic fibers (Cuadros and Ríos, 1988, Ozeki et al., 2000, Morcillo et al., 2006). However, more detailed studies in interference models (i.e. KO mice, in vivo manipulation in chick, frogs and fishes) will be necessary to more precisely define the function of this phase of PCD.

At these stages, scattered dying cells can also be found and they are normally most abundant in the central retina. Some studies have characterized these dying cells as proliferating/ mitotic cells (Table 2; Glücksmann, 1940; Díaz et al., 1999; Li etal., 2000; Candal et al., 2005). This observation may just be a consequence of their nature as proliferating neuroepithelial cells, or it may indicate a functional coupling between proliferation and cell 
TABLE 3

\section{DEVELOPMENTAL TIMING OF RETINAL GANGLION CELLS}

\begin{tabular}{|c|c|c|c|}
\hline Species & First RGCs born & First optic fibers reach extraretinal targets & References \\
\hline Zebrafish & Hpf 28 & Hpf 44 & $\begin{array}{l}\text { Burrill and Easter, } 1994 \\
\text { Schmitt and Dowling, 1994, } 1996 \text { and } 1999\end{array}$ \\
\hline Medaka & Stg 26 & Stg 32 & $\begin{array}{l}\text { Iwamatsu, } 1994 \\
\text { Yoda et al., } 2004\end{array}$ \\
\hline African cichlidae fish & Before Dpf 4 & Dpf 5 & $\begin{array}{l}\text { Presson and Fernald, } 1986 \\
\text { Hagedorn and Fernald, } 1992\end{array}$ \\
\hline Brown trout & $11 \mathrm{~mm}$ & $11 \mathrm{~mm}$ & $\begin{array}{l}\text { Mansour-Robaey and Pinganaud, } 1996 \\
\text { Candal et al., } 2005\end{array}$ \\
\hline Grass frog & Hpf 24 & & Glücksmann, 1940 \\
\hline Clawed frog & Stg 32 & Stg 35 & $\begin{array}{l}\text { Nieuwkoop and Faber, } 1967 \\
\text { Jenkins and Straznicky, } 1986\end{array}$ \\
\hline Turtle & E16 & E29 & $\begin{array}{l}\text { Hidalgo-Sánchez et al., } 2006 \\
\text { Francisco-Morcillo et al., } 2006\end{array}$ \\
\hline Chick & E2 & E9 & $\begin{array}{l}\text { Dreher and Robinson, } 1988 \\
\text { Prada et al., } 1991\end{array}$ \\
\hline Quail & & E7 & Senut and Alvarado-Mallart, 1986 \\
\hline Wallaby & & P85 & $\begin{array}{l}\text { Braekevelt et al., } 1986 \\
\text { Beazley et al, } 1988\end{array}$ \\
\hline Cat & E19 & E48 & $\begin{array}{l}\text { Walsh et al., } 1983 \\
\text { Williams et al., } 1986\end{array}$ \\
\hline Ferret & E22 & E28 & $\begin{array}{l}\text { Linden et al., } 1981 \\
\text { Cucchiaro and Guillery, } 1984 \\
\text { Reese et al., } 1994 \text { and } 1996\end{array}$ \\
\hline Rabbit & E16 & E21 & $\begin{array}{l}\text { Dreher and Robinson, } 1988 \\
\text { Crabtree, } 1989 \text { and } 1990\end{array}$ \\
\hline Mouse & E10 & E16 & $\begin{array}{l}\text { Godement et al., } 1984 \\
\text { Cepko et al., } 1996\end{array}$ \\
\hline Rat & E14 & E16 & $\begin{array}{l}\text { Horsburgh and Sefton, } 1987 \\
\text { Dreher and Robinson, } 1988 \\
\text { Galli-Resta et al., } 1996\end{array}$ \\
\hline Hamster & E10 & & Sengelaub et al., 1986 \\
\hline Guinea pig & E24 & & Langford and Sefton, 1992 \\
\hline Human & Before week 8 & & $\begin{array}{l}\text { Provis et al., } 1985 a \\
\text { Sturrock, } 1987\end{array}$ \\
\hline
\end{tabular}

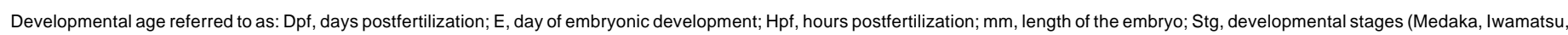
1994; Clawed frog, Nieuwkoop and Faber, 1967); week, gestational week.

TABLE 4

\section{EARLY NEURAL DEATH DURING GENERATION OF RETINAL GANGLION CELLS}

\begin{tabular}{|c|c|c|c|}
\hline Species & Developmental stage range $\&$ (peak) & Process, distribution \& magnitude & References \\
\hline Zebrafish & Hpf 20-48 (Hpf 36) & No proliferating cells dying. 68 apoptotic cells per retina. $0.2 \%$ of dying cells in the GCL. & $\begin{array}{l}\text { Li et al., } 2000 \\
\text { Cole and Ross, } 2001\end{array}$ \\
\hline Medaka & Stg 26-28 (Stg 26) & 50 apoptotic cells per retinal section. & lijima and Yokohama, 2007 \\
\hline Brown trout & $12-13 \mathrm{~mm}$ & 50 apoptotic cells $/ \mathrm{mm}^{2}$. & Candal et al., 2005 \\
\hline Clawed frog & Stg 32-36 & PCD in all layers of neuroepithelium. & Hensey and Gautier, 1998 \\
\hline Chick & E2-6 (E3.5-4) & Proliferating cells dying. 12.000 apoptotic cells $/ \mathrm{mm}^{2} .1680$ pyknotic fragments. & $\begin{array}{l}\text { Martín-Partido et al, } 1988 \\
\text { Frade et al., } 1996 \\
\text { Díaz et al., 2000; } \\
\text { Mayordomo et al., 2003; Chavarría et al., } 2007\end{array}$ \\
\hline Cat & E19-33 (E28) & PCD surrounding the optic fissure between E19 to E23. $0.23 \%$ of RGCs dying at E28. & Willians et al., 1986 \\
\hline Ferret & E25 & PCD surrounding the optic fissure after its closing. & Strongin and Guillery, 1981 \\
\hline Mouse & $\mathrm{E} 15.5-17.5$ (E16.5) & $0.5 \%$ of cells dying in the NBL. & Péquignot et al., 2003 \\
\hline Hamster & E12 & PCD surrounding optic fissure after its closing. & Strongin and Guillery, 1981 \\
\hline
\end{tabular}

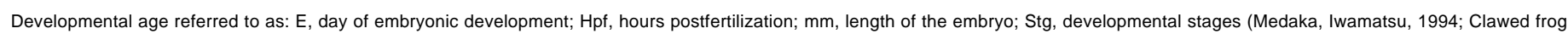
Nieuwkoop and Faber, 1967). Abbreviations: GCL, Ganglion Cell Layer; NBL. Neuroblastic Layer; PCD, Programmed Cell Death; RGC: Retinal Ganglion Cell.

death, for example as a mechanism to correct DNA replication or mitotic errors. However, while proliferating cells are evenly disseminated in the retina at these stages (Fig. 2B), the concentration of cell death in the central retina is maintained during early retinal development and later, it is clearly better correlated with cells leaving the cell cycle rather than with cycling cells (see below; Fig. 2, C-E; Díaz etal., 2000). Thus, the abundance of dying cells in the central retina may better reflect the onset of the next phase of PCD (see below).
While cell death in the initial stages of eye morphogenesis and retinal development is unequivocally documented (Table 2), quantitative studies of these events are very scarce. Thus, the relative magnitude of morphogenic cell death can only be extrapolated from comparative studies that are performed by the same laboratory using the same method. In the trout (Candal et al., 2005), the density of apoptotic cells in the selective locations where morphogenic cell death is taken place is 10-fold higher than that at any other later phase 
affecting retinal ganglion cells (RGCs). In mouse (Péquignot et al., 2003), a similar comparison renders $2 \%$ of dying cells at E10.5 whereas at P2, 3.5\% of cells in the ganglion cell layer (GCL) undergo PCD during the neurotrophic cell death phase. The available data cannot be extrapolated to determine the cumulative numbers of cells eliminated during morphogenic cell death, which characteristically seems to involve a high density of dying cells in defined, narrow spatiotemporal coordinates (Fig. 2A).

\section{Early neural cell death affecting retinal ganglion cell generation}

RGCs are the first differentiated cell type generated during retinal development and RGC neurogenesis seems to start in the late period of eye morphogenesis or immediately afterwards (Table 3). RGC progenitors leave the cell cycle following a central-to-peripheral gradient, at least in the best characterized species (Prada et al., 1991). A number of studies have described a phase of PCD that follows the closure of the optic fissure, concomitant with the initiation of differentiation in the retina (Table 4). However, this phase is not always recognized as an independent death event and adequately characterized as such.

A few studies over an extended period of retinal developmental have identified this early phase as an independent developmental PCD event and enabling the relative magnitude to be compared. In various fishes, it is not always easy to isolate the peaks of morphogenetic and early neural cell death, probably due to the accelerated initial development when compared to higher vertebrates (Candal et al., 2005; lijima and Yokohama, 2007). In chick (Martín-Partido etal., 1988), the numbers reported are very similar for the morphogenetic and early neural phases (1515 vs. 1680 pyknotic fragments, respectively). In the mouse, it is again impossible to isolate these peaks of cell death (Péquignot et al., 2003).

The situation is more clearly defined for later neurotrophic cell death. In the chick (Chavarría et al., 2007), apoptotic cells are tightly present in the central retina at E3-5 (Figs. 3, A-C, and 4A). After a period of little PCD (E6-8, Figs. 3, D and E, and 4A), cell death resurges again and sequentially affects the ganglion cell layer (GCL, peak at E9, Figs. 3, E-H, and 4B), the inner nuclear layer (INL; peak at E11, Figs. 3, F-K, and 4B), and to a small extent the outer nuclear layer (ONL). The density of apoptotic cells during the early peak of PCD, concomitant with RGC generation, is more than 20 -fold higher than in the peak of neurotrophic cell death affecting the GCL. In the mouse, the early phase of neural cell death (difficult to identify as mentioned above) appears to be moderate, with $0.5 \%$ of the cells in the neuroblast layer undergoing apoptosis at E12.5 (Péquignot etal., 2003). Later, and also in the central retina, the peak of PCD at P2 reaches $3.5 \%$ of cells in the GCL. In the cat (Williams et al., 1986), $0.23 \%$ of the cells are dying at E28 in the forming GCL in comparison with $0.4 \%$ of RGCs with axons that undergo apoptosis at E44-48. Although the peak of early neural cell death is difficult to define in the brown trout (Candal et al., 2005), the incidence of cell death in the corresponding stages $(12-13 \mathrm{~mm})$ is identical to the later PCD in the GCL ( $17 \mathrm{~mm} ; 50$ apoptotic cells $/ \mathrm{mm}^{2}$ ). These numbers essentially indicate that the relative magnitude of early neural cell death is comparable with that of the subsequent neurotrophic cell death. The differences observed between species may correlate with the difference in the timing of neurogenesis and the cell composition of the respective retinas.
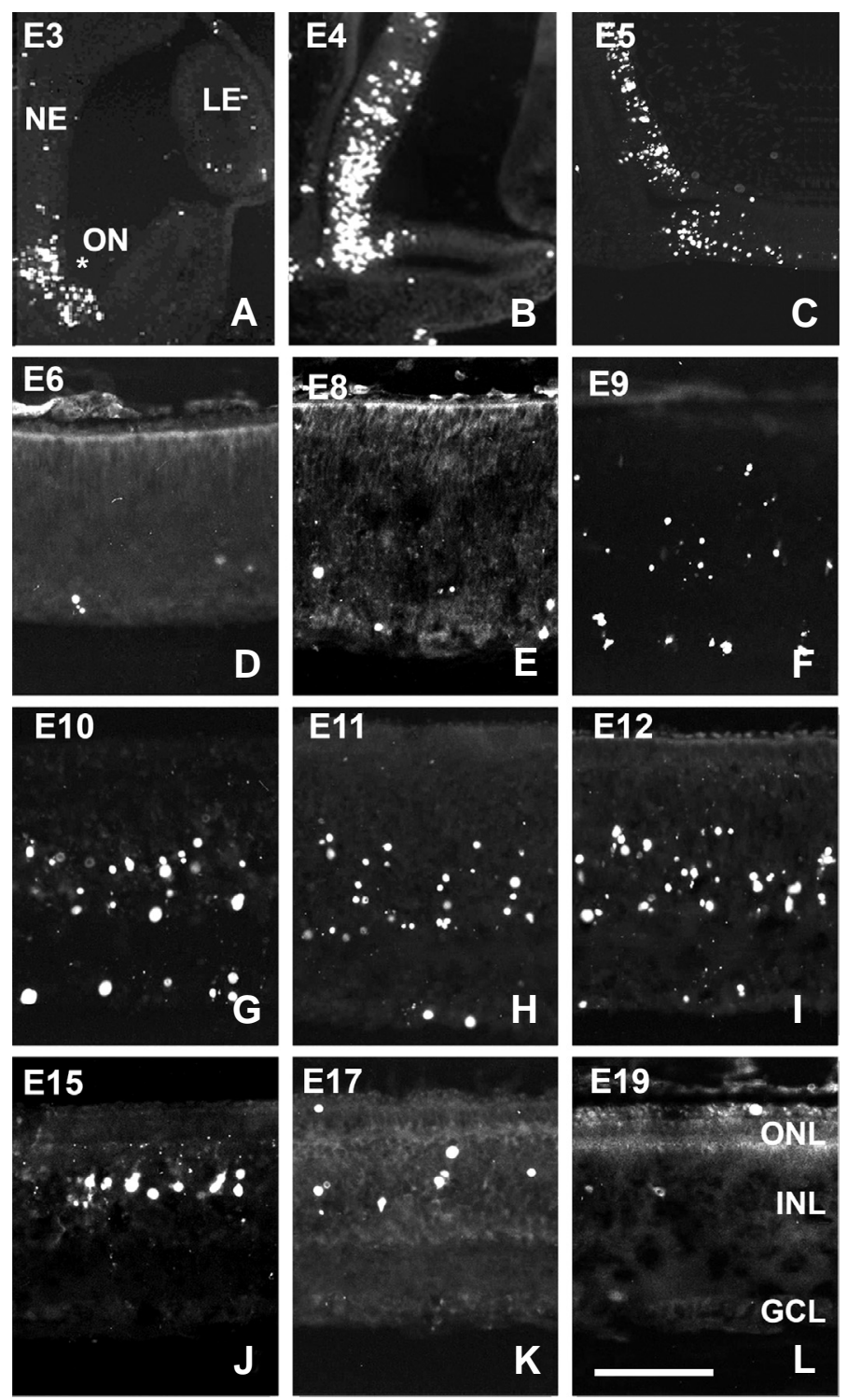

Fig. 3. Developmental course of cell death in the embryonic chick retina. Dying cells were identified by TUNEL (white spots) in retinal sections of the indicated embryonic age (E). The retinal layers (GCL, ganglion cell layer; INL, inner nuclear layer; ONL, outer nuclear layer) are formed sequentially as development proceeds. The asterisk indicates the exit point of the optic nerve. Additional retinal features labeled include. $N E$, neuroepithelium; LE, lens; ON, optic nerve). Bar represents $400 \mu \mathrm{m}$ in (A-C) and $200 \mu \mathrm{m}$ in (D-L). Reproduced from Chavarría et al., 2007 with permission. (c) 2007 Wiley Periodicals Inc.

Interestingly, the phase of early neural cell death is clearly simultaneous with the generation of RGCs, but not with the generation of later neuronal phenotypes (Prada et al., 1991; Cepko et al., 1996; Péquignot et al., 2003; Chavarría et al., 2007). This may indicate that RGCs are more selectively prone to die during their generation. Alternatively, PCD associated with the generation of other neuronal cell types may be masked by later, overlapping phases of neurotrophic cell death. While the latter alternative deserves further study using combined labeling (ie: with markers to determine the time of cell cycle exit together with specific neuronal 
markers), the former has been demonstrated by in vivointerference studies. In ovo exposition of chick embryos to caspase inhibitors at $\mathrm{HH} 17$ decreases apoptosis and doubles the number of RGC (Figs. 5 and 6; Mayordomo etal., 2003). Conversely, treatment between E2 and E6 with antibodies that block the insulin receptor increases apoptosis and halves the number of RGCs (Figs. 7 and 8), reflecting the survival signals mediated by this receptor in early development (Hernández-Sánchez et al., 2006). Furthermore, overexpression of the proapototic molecule Bax in neurulating chick embryos results in a moderate reduction in the number of RGCs at E9 $(10-20 \%$, Sato et al., 2006). Similarly, genetic deletion of Dlx1/Dlx2 in the mouse increases apoptosis at E13.5 and E16.5, as well as decreases RGC number by $34 \%$ (De Melo etal., 2005). Thus, the generation of RGCs is a process that is undoubtedly subject to PCD.

These different approaches also provide cumulative quantification and thus, at least, $50 \%$ of the ganglion cells generated are selected by PCD shortly alter birth, a magnitude equivalent to that of neurotrophic cell death of RGCs. Certainly, early neural cell death deserves further studies to assess its selectivity for RGCs and to determine how widespread this process is, especially in those species where peaks of PCD are not easily identified, and more importantly, as well as to characterize its function.

\section{Neurotrophic cell death of retinal ganglion cells}

RGCs are a paradigm of neurotrophic support/death. A com-

\section{TABLE 5}

\section{NEUROTROPHIC CELL DEATH IN THE GANGLION CELL LAYER}

\begin{tabular}{|c|c|c|c|}
\hline Species & Developmental stage range $\&$ (peak) & Process, distribution \& magnitude & References \\
\hline Zebrafish & $\begin{array}{l}\text { Dpf 2-5 (Dpf 3) } \\
\text { Dpf 5-9 (Dpf 7) }\end{array}$ & $\begin{array}{l}\text { Extraretinal synaptogenesis. } \\
1.09 \% \text { of dying cells in the GCL. } \\
\text { Intraretinal synaptogenesis and initial visual activity. } 0.22 \% \text { of } \\
\text { dying cells in the GCL. }\end{array}$ & Biehlmaier et al., 2001 \\
\hline African cichlid fish & Dpf 4-6 (Dpf 5) & $\begin{array}{l}\text { Extraretinal synaptogenesis. } \\
20 \text { apoptotic cells } / \mathrm{mm}^{2} \text {. }\end{array}$ & Hoke and Fernald, 1998 \\
\hline Brown trout & $15-24 \mathrm{~mm}(17 \mathrm{~mm})$ & $\begin{array}{l}\text { Intraretinal synaptogenesis and initial visual activity. } 50 \text { apoptotic } \\
\text { cells } / \mathrm{mm}^{2} \text {. }\end{array}$ & Candal et al., 2005 \\
\hline Clawed frog & $\begin{array}{l}\text { Stg } 53 \text { and } \\
\text { metamorphosis }\end{array}$ & $\begin{array}{l}\text { Extraretinal synaptogenesis. } \\
\text { Loss of } 20 \% \text { of generated RGC Metamorphosis. } 40-70 \% \text { of } \\
\text { RGCs born at Stg } 32-49 \text {. }\end{array}$ & Gaze and Grant, 1992 \\
\hline Turtle & E23-64 (E31-34) & $\begin{array}{l}\text { Extraretinal synaptogenesis. } \\
120 \text { apoptotic cells } / \mathrm{mm}^{2} \text { at E31. Loss of } 40 \% \text { of RGCs generated. }\end{array}$ & $\begin{array}{l}\text { Francisco-Morcillo et al., } 2004 \\
\text { Hidalgo-Sánchez et al., } 2006\end{array}$ \\
\hline Chick & $\begin{array}{l}\text { E8-11 (E9) } \\
\text { E7-18 (E13) }\end{array}$ & $\begin{array}{l}\text { Extraretinal synaptogenesis. } \\
539 \text { apoptotic/mm in the GCL at E9. Loss of } 40 \% \text { of RGCs } \\
\text { generated. }\end{array}$ & $\begin{array}{l}\text { Rager and Rager, } 1979 \\
\text { Cook et al., } 1998 \\
\text { Chavarría et al., } 2007\end{array}$ \\
\hline Quail & $\mathrm{E} 8-13(\mathrm{E} 9-11)$ & $\begin{array}{l}\text { Extraretinal synaptogenesis. } \\
500 \text { apototic cells } / \mathrm{mm}^{2} \text { in the } G C L \text { at E10. }\end{array}$ & Marín-Teva et al., 1999 \\
\hline Wallaby & P30-100 (P50) & $\begin{array}{l}\text { Extraretinal synaptogenesis. } \\
1 \% \text { of dying cells in the GCL at P50. Loss of } 30 \% \text { of RGCs } \\
\text { generated. }\end{array}$ & Dunlop and Beazley, 1987 \\
\hline Cat & $\mathrm{P} 12-84(\mathrm{P} 12-36)$ & $\begin{array}{l}\text { Extraretinal synaptogenesis. } 3-10 \% \text { of dying cells in the centro- } \\
\text { temporal retina at E40. } 0.44 \% \text { of dying cells in the GCL at E44- } \\
\text { E48. } \\
\text { Intraretinal synaptogenesis and initial visual activity. } 0.22 \% \text { dying } \\
\text { cells in the GCL. } \\
\text { All processes account for the loss of } 76 \% \text { of the RGCs generated. }\end{array}$ & $\begin{array}{l}\text { Williams et al., } 1986 \\
\text { Wong and Hughes, } 1987\end{array}$ \\
\hline Ferret & P0 to $\mathrm{P} 8$ & Extraretinal synaptogenesis. $5 \mathrm{TUNEL}^{+}$cells $/ \mathrm{mm}^{2}$ in the GCL. & $\begin{array}{l}\text { Henderson et al., } 1988 \\
\text { Cusato et al., } 2001\end{array}$ \\
\hline Rabbit & E23-P42 & Loss of $62 \%$ of the RGCs generated. & Robinson et al., 1987 \\
\hline Mouse & $\begin{array}{l}\text { E18.5 to P12 (P2) } \\
\text { P13-21 (P15) }\end{array}$ & $\begin{array}{l}\text { Extraretinal synaptogenesis. } 3.5-8.6 \% \text { of dying cells in the GCL. } \\
1 \% \text { of dying RGCs. } \\
\text { Intraretinal synaptogenesis and initial visual activity. } 2.3 \% \text { of } \\
\text { cells dying in the GCL. } \\
\text { All processes account for the loss of } 60 \% \text { of the RGCs generated. }\end{array}$ & $\begin{array}{l}\text { Young, } 1984 \\
\text { Williams et al., } 1990 \\
\text { Bonfanti et al., } 1996 \\
\text { Péquignot et al., } 2003 \\
\text { Pollock et al., } 2003\end{array}$ \\
\hline Rat & $\mathrm{P} 0-14(\mathrm{P} 4)$ & $\begin{array}{l}\text { Extraretinal synaptogenesis. Loss of } 35-90 \% \text { of the RGCs } \\
\text { generated. } \\
\text { Intraretinal synaptogenesis and initial visual activity. } 50 \% \text { of the } \\
\text { RGCs generated die from P0 to P14. }\end{array}$ & $\begin{array}{l}\text { Potts et al., } 1982 \\
\text { Perry, } 1983 \\
\text { Horsburgh and Sefton, } 1987 \text { Galli-Resta and Ensini } 1996\end{array}$ \\
\hline Hamster & $\mathrm{P} 0-10$ & $\begin{array}{l}\text { Extraretinal synaptogenesis. Loss of } 25-50 \% \text { of the RGCs } \\
\text { generated. }\end{array}$ & $\begin{array}{l}\text { Sengelaub and Finaly, } 1982 \\
\text { Sengelaub et al., } 1986\end{array}$ \\
\hline Guinea Pig & E30-45 (E36) & $\begin{array}{l}\text { Extraretinal synaptogenesis. } 2.2 \% \text { dying cells in the GCL at E36. } \\
\text { Loss of } 37 \% \text { of the RGCs generated. }\end{array}$ & Langford and Sefton, 1992 \\
\hline Rhesus monkey & & $\begin{array}{l}\text { Extraretinal synaptogenesis. Loss of } 50 \% \text { of the RGCs } \\
\text { generated. }\end{array}$ & Radick and Riley, 1983 \\
\hline Human & $\begin{array}{l}\text { Week12-30 } \\
\text { (week 16-21) }\end{array}$ & $\begin{array}{l}\text { Extraretinal synaptogenesis. Loss of } 70 \% \text { of the RGCs } \\
\text { generated. }\end{array}$ & $\begin{array}{l}\text { Provis et al., 1985b } \\
\text { Provis and Van Driel, } 1985 \\
\text { Provis, } 1987 \\
\text { Sturrock, } 1987\end{array}$ \\
\hline
\end{tabular}

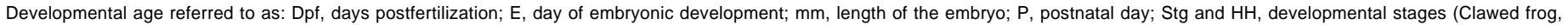
Nieuwkoop and Faber, 1967; Chick, Hamburger and Hamilton, 1951); week, gestational week. Abbreviations: GCL, Ganglion Cell Layer; RGC, Retinal Ganglion Cell. 


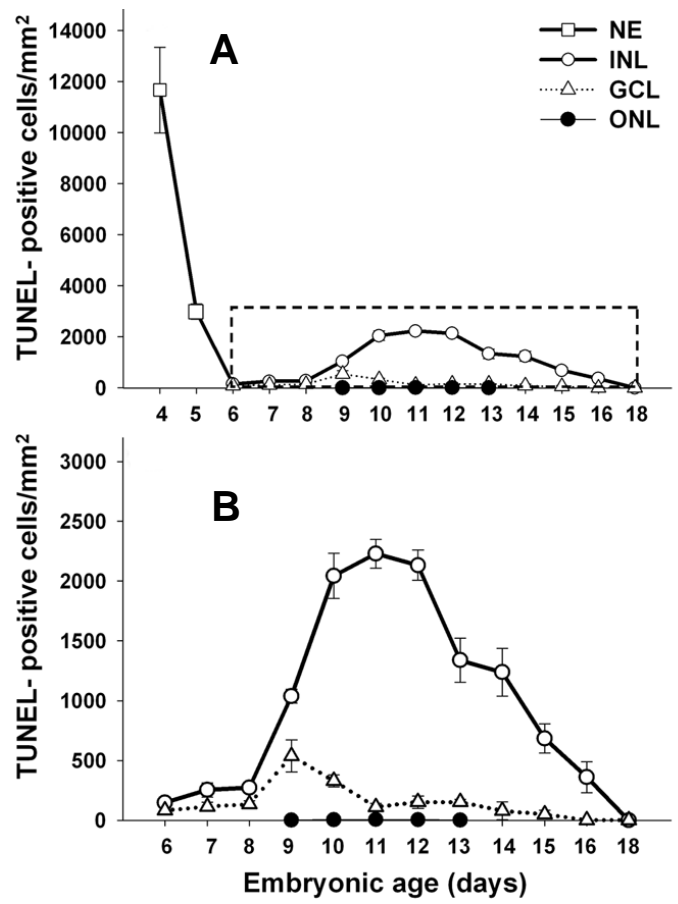

parative analysis of several species (Table 5) shows that RGCs are affected by two consecutive, partially overlapping events during the second half of retinal development. The first follows the postulate of the neurotrophic theory: the axons of the RGCs form the optic nerve and, at their main target tissue (the optic tectum for non-mammalian vertebrates and the lateral geniculate nucleus for mammals), they compete for limiting amounts of BDNF, their best defined neurotrophic factor (Cohen-Cory and Lom, 2004). In addition, later RGC death has been reported in several species that seems to coincide with both, eye opening and a peak of cell death in the ONL (Table 5). Both events occur after RGC generation is
Fig. 4. Magnitude of cell death throughout embryonic chick retinal development. Density of cell death, expressed as TUNEL-positive nuclei per $\mathrm{mm}^{2}$, was quantified in the four most central fields of four sections per retina, such as those shown in Fig. 3. At early stages (E4-E6), the whole neuroepithelium (NE) was scored. The relative densities in the developing retinal layers were considered independently as early as the different layers were identifiable (GCL, ganglion cell layer; INL, inner nuclear layer; ONL, outer nuclear layer). (B) corresponds to the inset in(A) with an expanded scale for better visualization of layer specific cell death. Values represent the mean $\pm S D$ of four independent retinas at each age. Reproduced from Chavarría et al., 2007 with permission. () 2007 Wiley Periodicals Inc.

completed and thus, the cumulative number of RGCs affected can be easily calculated by comparing the number of axons in the optic nerve before and after this phase of PCD. The loss of RGCs during this period is species-dependent and ranges from 30 to $75 \%$ (Table 5), emphasizing the importance of this physiological process for establishing the connectivity of the nervous system. Since early neural cell death affecting recently born RGCs seems to be of a similar magnitude, the functional relevance in retinal development may be similar and it certainly deserves more attention.

\section{Late neuronal cell death in other retinal layers}

Most neuronal cell types in the retina are affected by PCD after the neurotrophic peak in the GCL (Figs. 3 and 4). Although an exhaustive discussion of this PCD is beyond the scope of this review, we have referred to these events in Table 6 to provide a comprehensive overview of cell death during retinal development.

\section{Regulation of retinal cell death}

Genetically modified mice and in vivo manipulation of nonmammalian vertebrates have confirmed the importance of neuronal cell death in the postulate of the neurotrophic theory, including that of the RGCs. This kind of approach usually provides

\section{TABLE 6}

\section{LATE NEURONAL CELL DEATH IN OTHER RETINAL LAYERS}

\begin{tabular}{|c|c|c|c|}
\hline Species & Developmental stage range $\&$ (peak) & Process, distribution \& magnitude & References \\
\hline Zebrafish & $\begin{array}{l}\text { Dpf 5-9 (Dpf 6) } \\
\text { Dpf 6-27 (Dpf 7) }\end{array}$ & $\begin{array}{l}0.2 \text { of dying cells in the INL. } \\
1.1 \% \text { of dying cells in ONL. }\end{array}$ & Biehlmaier et al., 2001 \\
\hline Chick & $\mathrm{E} 8-20$ (E10-12 and E17-18) & $\begin{array}{l}\text { PCD affecting to postmitotic cells. } 2229 \text { apoptotic cells } / \mathrm{mm}^{2} \text { in the INL. } 35 \text { apoptotic TrkA } A^{+}-A C \\
\text { cells } / \mathrm{mm}^{2} \text {. Less than } 1 \% \text { of cells dying in the ONL. }\end{array}$ & $\begin{array}{l}\text { Cook et al., } 1998 \\
\text { Karlsson et al., } 2001 \\
\text { Turner et al., } 2006 \\
\text { Chavarria et al., } 2007\end{array}$ \\
\hline Quail & E8 to $\mathrm{P} 3(\mathrm{E} 12)$ & 3000 apoptotic cells $/ \mathrm{mm}^{2}$ in the INL. & Marin-Teva et al., 1999 \\
\hline Cat & $\begin{array}{l}\text { E50 to P17 (E58 and P2) } \\
\text { P20-30 (P25) }\end{array}$ & $\begin{array}{l}\text { AC. } 72,000 \text { apoptotic cells. } \\
\text { Ectopic PhRs in the outer part of the INL. } 6 \text { TUNEL }{ }^{+} \text {cells } / \mathrm{mm}^{2} .65,000 \text { apoptotic cells. } \\
25 \mathrm{TUNEL} \mathrm{T}^{+} \mathrm{PhR} / \mathrm{mm}^{2} \text { in the ONL. }\end{array}$ & $\begin{array}{l}\text { Williams et al., } 1986 \\
\text { Wong and Hughes, } 1987 \\
\text { Robinson, } 1988 \\
\text { Maslin et al., } 1997\end{array}$ \\
\hline Ferret & P3-42 (P22) & 20 TUNEL $L^{+}$cells $/ \mathrm{mm}^{2}$ in the INL. & Cusato et al., 2001 \\
\hline Mouse & P3-21 (P4, P7, P8-10 and P15) & $\begin{array}{l}\left.2.8 \% \text { of dying cells in INL ( } 60 \text { TUNEL }{ }^{+} \text {cells } / \mathrm{mm}^{2}\right), 6.4 \% \text { of dying BC or } M C, 7.8 \% \text { of dying } A C, 3.3 \% \\
\text { of dying rods, } 0.6 \% \text { dying cells in the ONL }\left(15 \text { TUNEL cells } / \mathrm{mm}^{2}\right) \text {. }\end{array}$ & $\begin{array}{l}\text { Young, } 1984 \\
\text { Portera-Caulliau et al., } 1994 \\
\text { Mervin and Stone, } 2002 \\
\text { Péquignot et al., } 2003\end{array}$ \\
\hline Rat & $\mathrm{P} 1-30$ (P4, P6-7, P10 and P15-22) & 3-8\% of dying cells in the INL die (30 TUNEL cells $\left./ \mathrm{mm}^{2}\right) .25$ TUNEL cells $/ \mathrm{mm}^{2}$ in the ONL. & $\begin{array}{l}\text { Vogel and Möller, } 1980 \\
\text { Spira et al., } 1984 \\
\text { Horsburg and Sefton, } 1987 \\
\text { Maslin et al., } 1997\end{array}$ \\
\hline Guinea pig & E39-E45 & $1 \%$ of dying $A C, 1.2 \%$ of dying $B C$. & Langford and Sefton, 1992 \\
\hline
\end{tabular}

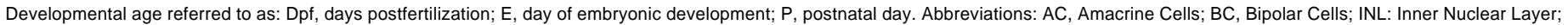
MC, Müller glial cells; ONL, outer nuclear layer; PhR, photoreceptor. 
information regarding both the regulatory pathways involved and the possible function. As discussed previously (de la Rosa and de Pablo, 2000; Boya and de la Rosa, 2005), the models available may also provide additional information beyond that considered at present. However, most of the genetic approaches employed to define the molecules that regulate PCD have analyzed the structure of the retina when development is finished. For instance, 3week-old caspase-3 null mutant mice show hyperplasia in all retinal layers (Kuida et al., 1996). Although this approach provides information on the final consequences of such genetic modifications, it does not reveal in which phase/s of cell death the molecule is involved.

A few studies have clearly identified modifications in the number of dying cells during the morphogenic cell phase as a result of experimental interference (Table 7). Antisense RNA interference with the serotonin receptor in the clawed frog (De Lucchini et al., 2005) and KO mice for BMP7 (Morcillo et al., 2006) show disturbances in the closure of the optic fissure, establishing a functional correlation between the molecules altered, PCD and this specific morphogenetic process. Other studies have characterized later consequences of the manipulation which deserve to be studied in more detail to determine whether they are secondary consequences of the modification of morphogenic cell death, or independent processes in which the altered molecule is involved.

The manipulations that increase or decrease in the numbers of dying cells during the early phase of neural cell death show reciprocal effects on RGC number (Table 8 ). Some studies have indicated that the normal phenotype is recuperated at later stages (Pimentel et al., 2000) suggesting a coupling of the different cell death phases to obtain the precise final numbers of RGCs. These observations offer clear evidence that the process of early neural cell death tightly controls the generation of RGCs in a precisely regulated fashion. Conversely, in terms of functional relevance, no clear suggestions on the role of this phase of cell death can be extrapolated from the observations available.

Finally, the survival/death of most retinal neurons at later developmental stages is regulated by multiple families of molecules that provide extrinsic and intrinsic signals (Tables 9 and 10), an extensively studied field.

\section{Concluding remarks}

The data presented in this review intends to facilitate the evaluation of several independent phases of cell death during vertebrate retinal development, some of which are little characterized. These distinct phases have been tentatively called morpho-

Fig. 5. Modulation of cell death and retinal ganglion cell generation by the pancaspase inhibitor Boc-D. HH17 chick embryos were treated in ovo for 6 (A-D) or $20 \mathrm{~h}$ (E-H) with the caspase inhibitor Boc-D-fmk (B,D,F,H), or the corresponding control (0.1\% DMSO; (A,C,E,G)). Wholemount retinas were double-stained for TUNEL to visualize dying cells (green spots in all panels) and with anti-lslet 1/2 antibody to reveal retinal

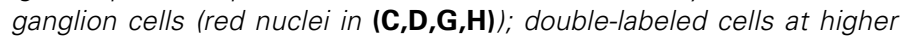
magnification in the area indicated by the asterisk in $(\mathbf{A}, \mathbf{B}, \mathbf{E}, \mathbf{F})$ ). Note that TUNEL-positive and Islet-1/2-positive apoptotic bodies appear as yellow spots. The final stage of the treated embryos was HH19 (A-D) or HH21 (E-H). Scale bar, $200 \mu \mathrm{m}$. Reproduced from Mayordomo et al., 2003 with permission. (c) 2003 European Neuroscience Association. genic cell death, early neural cell death and neurotrophic cell death. Neither the magnitude nor the precise regulation of the earlier phases when compared to the much better characterized neurotrophic cell death justifies neglecting their study when trying to obtain an integrated view of retinal development.

The most compelling issue is to understand the physiological meaning of selecting recently born RGCs through PCD. As postulated by the neurotrophic theory, the number of projecting neurons is adjusted to the target field and their connections are refined by a process of PCD. As suggested by some studies, number adjustment may be a multi-step process, a mechanism that may provide both greater flexibility and more precise regulation. Furthermore, we speculate that projecting neurons such as RGCs may have additional fitness and positional information requirements that are achieved by processes related to early neural cell death (extensively discussed in de la Rosa and de Pablo, 2000; Boya and de la
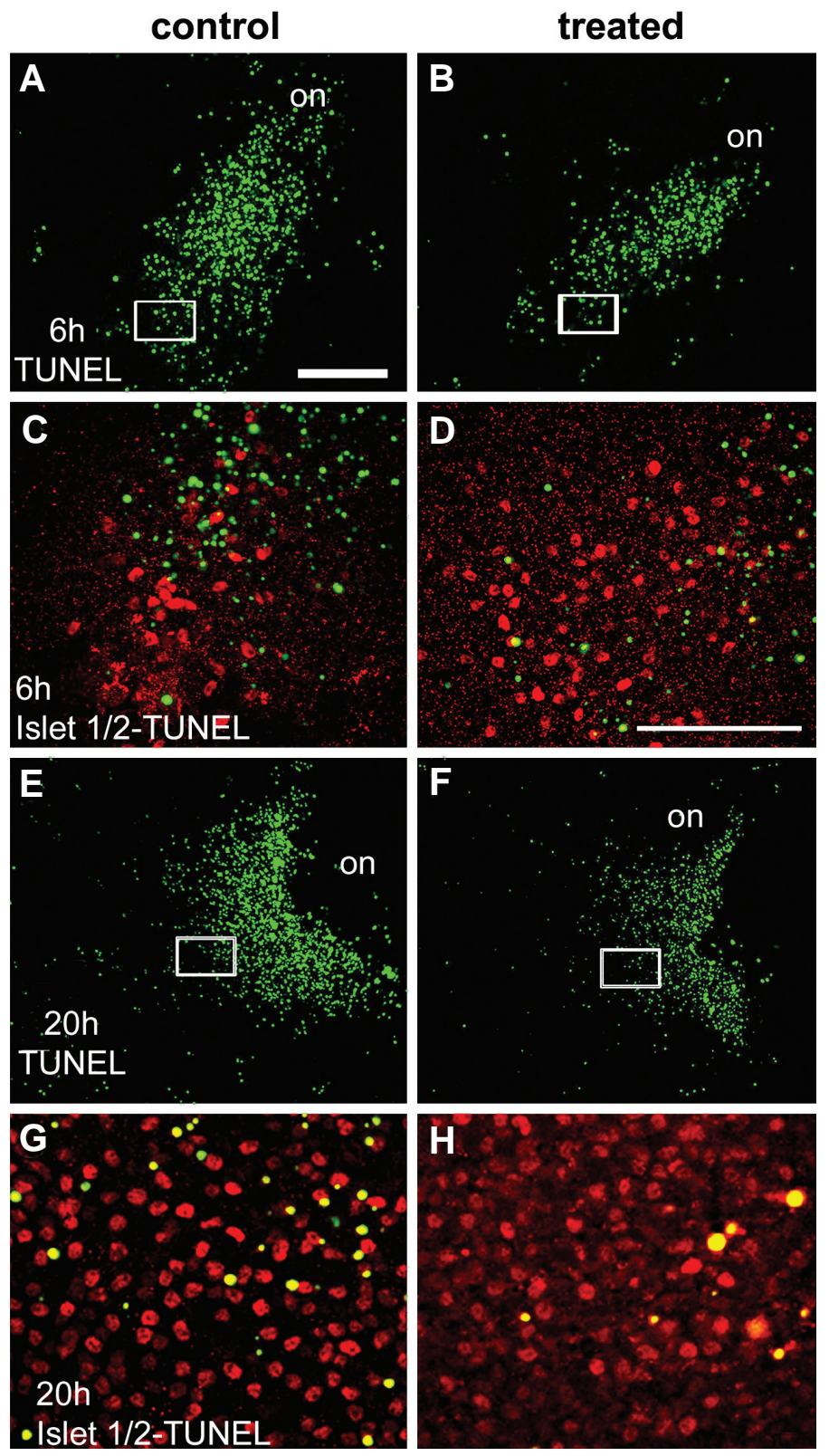


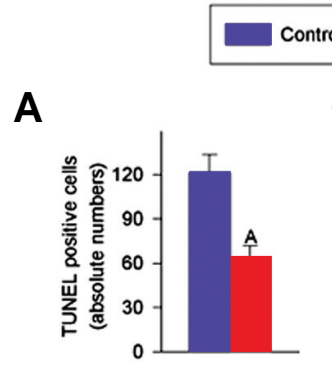

B

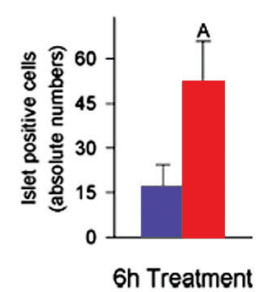

C

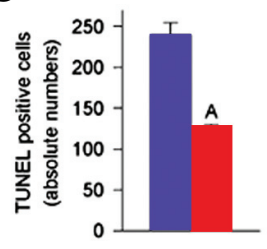

D

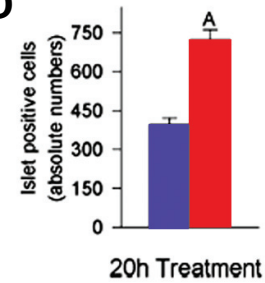

Control lgs
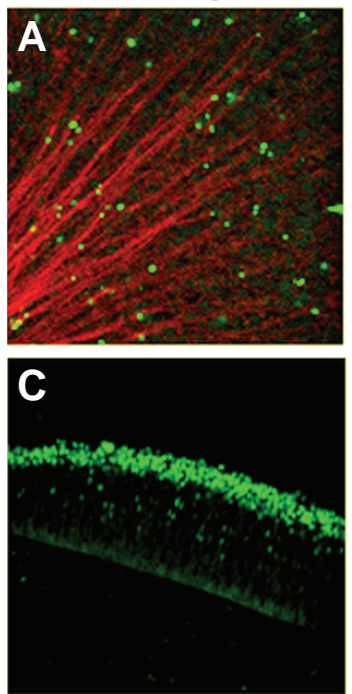

Insulin Receptor Igs

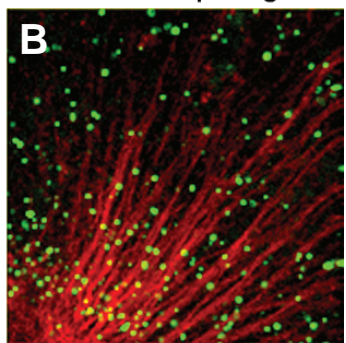

D

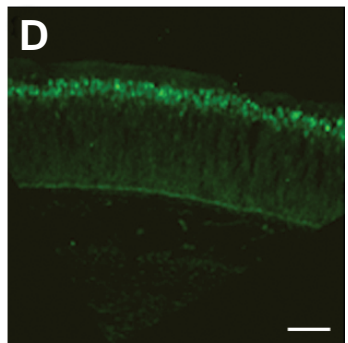

Fig. 6 (Left). Quantitative analysis of the effect of the pancaspase inhibitor Boc-D on cell death and retinal ganglion cell generation. $H H 17$ chick embryos were treated in ovo for 6 (A,B) or $20 \mathrm{~h}(\mathbf{C}, \mathbf{D})$ with the caspase inhibitor Boc-D-fmk, or the corresponding control (0.1\% DMSO). TUNELpositive apoptotic bodies (A,C) and Islet 1/2-positive nuclei (B,D) were scored in whole-mount retinas such as those shown in Fig. 5. The total number of positive cells are shown as the mean \pm SEM ( $n=8$ for all experimental conditions). $A, p<0.01$, Boc-D vs. control. Reproduced from Mayordomo et al., 2003 with permission. (c) 2003 European Neuroscience Association.

Fig. 7 (Right). Modulation of cell death and retinal ganglion cell generation by blocking insulin signaling. E2 chick embryos were treated in ovo for 2 (A,B) or 4 days (C,D) with anti-insulin receptor lgs (B,D) or with the corresponding control lgs (A,C). The neuroretinas were processed in whole-mount $(A, B)$ or sections $(C, D)$, and TUNEL (green in $(A, B)$ ) was used to characterize dying cells. Immunostaining for G4/Ng-CAM (red in (A,B) or for Islet1/2 (green in $(C, D)$ ) was used to identify the retinal ganglion cells axons and nuclei, respectively. (A,B) Superimposed confocal microscope images illustrate the distribution of the dead cells surrounding the optic nerve head and the retinal ganglion cell axons at E4, after 2-days of treatment. Note the increase of TUNEL-positive nuclei in the retina treated with the blocking antibody against the insulin receptor. (C,D) Fields adjacent to the optic nerve from retinal sections at E6 after 4-days of treatment. Note the reduced number of Islet1/2-positive cells in the retina treated with the blocking antibody against the insulin receptor. Scale bar, $40 \mu \mathrm{m}$. Reproduced from Díaz et al., 2000 with permission. (O 2000 The Company of Biologists.

TABLE 7

\section{REGULATION OF MORPHOGENIC CELL DEATH IN RETINAL DEVELOPMENT}

Molecule / experimental approach
GDF6 (BMP13)
Treatment of clawed frog embryos (2-cell Stg) with antisense
morpholinos.
Serotonin
Treatment of clawed frog embryos (2-cell stage) with
antisense morpholinos to $5-\mathrm{HT}_{2}$ receptor.
Treatment of Stage $15-17$ clawed frog embryos with $5-\mathrm{HT}_{2}$
receptor antagonist.
Biotin
In ovo treatment of $\mathrm{HH} 14-17$ chick embryos with biotin.
BMP4
In ovo treatment of HH14 chick embryos with BMP4.
In ovo treatment of HH14 chick embryos with noggin.
BMP7
KO mouse.
FasL
Gld mouse (fas/ KO mouse).
Msx2
Overexpressing transgenic mouse.
P75
KO mouse.

Cell death phenotype

Apoptotic cells increase at Stg 27.

Apoptotic cells increase at $\operatorname{Stg} 40$.

Apoptotic cells increase at Stgs 15, 28, 33.

Apoptotic cells decrease at $\mathrm{HH} 17$.

Apoptotic cells increase at $\mathrm{HH} 17$. Apoptotic cells decrease at $\mathrm{HH} 17$.

Apoptotic cells decrease at E10.5

Apoptotic cells decrease $50 \%$ in the NBL at E10.5.

Apoptotic cells increase at E9.5.

$42 \%$ decrease in apoptotic cells at E12. No ND during the morphogenic phase reduction observed between $\mathrm{E} 13$ and $\mathrm{P} 0$.

Retinal phenotype

ND during the morphogenic phase. Stg 41 . thickness of the retina.

ND.

No altered phenotype in adults.

Thinner neuroepithelium at E9.5

Thinner neuroepithelium
Lack of RGCs at E14.5.
References

Strong reduction of several types of mature neurons at

Alterations in the closure of optic fissure and reduction of the GCL at Stg 40-42. Microphtalmia.

De Lucchinni et al., 2005

Alterations in the morphogenesis of the eye. Increased

Valenciano et al., 2002

Alterations in the closure of optic fissure.

Cell number increases $150 \%$ in NBL at E10.5.

Hanel and Hensey, 2006 No altered phenotype at P0, P5, P10 and P40.

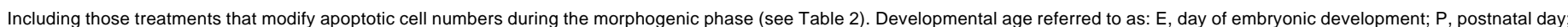

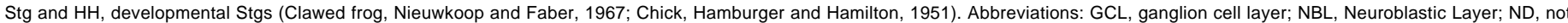
determined; RGCs, Retinal Ganglion Cells 
TABLE 8

\section{REGULATION OF EARLY NEURAL CELL DEATH IN RETINAL DEVELOPMENT}

\begin{tabular}{|c|c|c|c|}
\hline Molecule / experimental approach & Cell death phenotype & Retinal phenotype & References \\
\hline $\begin{array}{l}\text { Cdh4 (cadherin-4) } \\
\text { Treatment of zebrafish embryos with antisense } \\
\text { morpholinos. }\end{array}$ & Apoptotic cells increase 3 -fold at $\mathrm{Hpf} 36$ and 50. & Reduction of the GCL and optic fibers at Hpf 48 . & Babb et al., 2005 \\
\hline $\begin{array}{l}\text { Serotonin } \\
\text { Treatment of clawed frog embryos (2-cell Stg) with } \\
\text { antisense morpholinos to } 5-\mathrm{HT}_{2} \text { receptor. } \\
\text { Treatment of Stg } 15-17 \text { clawed frog embryos with } 5-\mathrm{HT}_{2} \\
\text { receptor antagonist. }\end{array}$ & $\begin{array}{l}\text { Apoptotic cells increase at Stg } 40 . \\
\text { Apoptotic cells increase at Stgs } 15,28,33 .\end{array}$ & $\begin{array}{l}\text { Alterations in the closure of optic fissure and reduction } \\
\text { of the GCL at Stg } 40-42 \text {. Microphtalmia. }\end{array}$ & De Lucchinni et al., 2005 \\
\hline $\begin{array}{l}\text { Bax } \\
\text { Overexpression in chick embryos by retroviral infection } \\
\text { at } \mathrm{HH} 9 \text {. }\end{array}$ & $\begin{array}{l}\text { Apoptotic cells increase in the GCL at E3 and } \\
\text { E6. }\end{array}$ & RGC number decreases $10-20 \%$ at E9. & Sato et al., 2006 \\
\hline $\begin{array}{l}\text { Caspases } \\
\text { In ovo treatment of } \mathrm{HH} 17 \text { chick embryos with caspase } \\
\text { inhibitors. }\end{array}$ & Apoptotic cells decrease $50 \%$ at $\mathrm{HH} 19$. & RGC number increases $50 \%$ at $\mathrm{HH} 20$. & Mayordomo et al., 2003 \\
\hline $\begin{array}{l}\text { Growth hormone } \\
\text { In ovo treatment of E2 chick embryos with blocking } \\
\text { antibodies against GH. }\end{array}$ & Apoptotic cells increase at E6. & ND. & Sanders et al., 2005 \\
\hline $\begin{array}{l}\text { Insulin } \\
\text { In ovo treatment of E2 chick embryos with blocking } \\
\text { antibodies against insulin and insulin receptor. }\end{array}$ & $\begin{array}{l}\text { Apoptotic cells increase } 60 \% \text { at E4. RGC } \\
\text { apoptotic cells increase } 250 \% \text { at E4. }\end{array}$ & RGC number decreases $50 \%$ at $E 6$. & Díaz et al., 2000 \\
\hline $\begin{array}{l}\text { Integrins } \\
\text { Injection of dominant-negative } \beta 1 \text { integrin into the } \\
\text { anterior neural tube of } \mathrm{HH} 11 \text { chick embryos. } \\
\text { In ovo treatment from E2 to E5 with } \alpha 4 \beta 1 \text { intregrin } \\
\text { antagonist. }\end{array}$ & $\begin{array}{l}\text { Apoptotic cells increase 5-fold at E6.5. } \\
\text { Apoptotic cells increase 3-fold at E6. }\end{array}$ & $\begin{array}{l}\text { RGC number decreases } 50 \% \text { at E6. Reduced } \\
\text { thickness of the retina. }\end{array}$ & Leu et al.,2004 \\
\hline $\begin{array}{l}\text { Raf } \\
\text { Overexpression in chick embryos by retroviral infection } \\
\text { of C-Raf at E4.5 of dominant-negative Raf C } 4 \text {. }\end{array}$ & Apoptotic cells reduced at E6.5 and E7.5. & RGC number decreases at E7.5. & Pimentel et al., 2000 \\
\hline $\begin{array}{l}\text { Apaf-1 } \\
\text { KO mouse. }\end{array}$ & $\begin{array}{l}\text { Not determined in the retina. Reduced apoptosis } \\
\text { in the nervous system. }\end{array}$ & Increased thickness of the retina at E12.5 and E14.5. & Cecconi et al., 1998 \\
\hline $\begin{array}{l}\text { Dlx1/DIx2 } \\
\text { KO mouse. }\end{array}$ & $\begin{array}{l}\text { Apoptotic cells increase } 3 \text {-fold at E13.5, } 66 \% \text { at } \\
\text { E16.5. No modification at E18.5. } \\
\text { Dying cells are RGC. }\end{array}$ & $\begin{array}{l}\text { No retinal phenotype at E13.5 and E16.5. RGC number } \\
\text { decreases } 34 \% \text { at E18.5. Optic fibres decrease } 23 \% \text { at } \\
\text { P0. }\end{array}$ & De Melo et al., 2005 \\
\hline $\begin{array}{l}\text { Phosphatidylserine Receptor } \\
\text { KO mouse. }\end{array}$ & Apoptotic cells increase 6-fold at E17.5. & ND. & Li et al., 2003 \\
\hline $\begin{array}{l}\text { Sortilin1 } \\
\text { KO mouse. }\end{array}$ & Apoptotic cells decrease $63 \%$ at E15.5. & ND. & Jansen et al., 2007 \\
\hline $\begin{array}{l}\text { Tlx } \\
\text { KO mouse. }\end{array}$ & $\begin{array}{l}\text { Apoptotic cells increase } 4 \text { fold from E16.5 to } \\
\text { E18.5. }\end{array}$ & $\begin{array}{l}\text { No retinal phenotype during embryonic period. GCL } \\
\text { increases thickness } 1.3 \text {-fold at } \mathrm{PO} \text {. }\end{array}$ & Miyawaki et al., 2004 \\
\hline
\end{tabular}

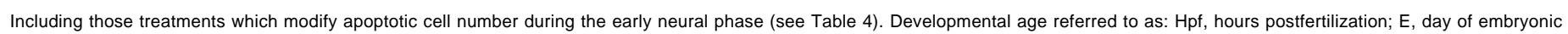

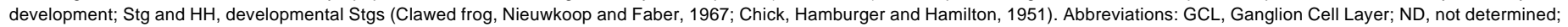
RGC, Retinal Ganglion Cell.

A

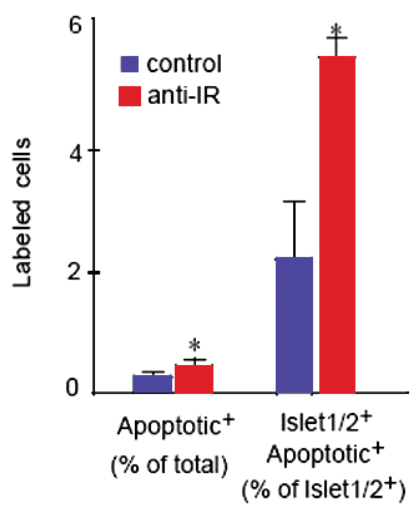

B

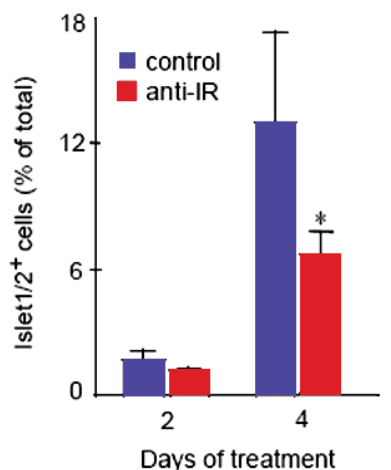

Fig. 8. Quantitative analysis of the effect of blocking insulin signaling on cell death and retinal ganglion cell generation. E2 chick embryos were treated in ovo for 2 or 4 days with anti-insulin receptor lgs $(\mathbf{A}, \mathbf{B})$ or the corresponding control lgs. The neuroretinas were dissociated to a single-cell suspension and stained with DAPI and with antiIslet1/2. (A) Relative incidence of apoptosis, after a 2-day exposure, in either the total populations or the Islet1/2-positive subpopulation. (B) Progressive reduction of the Islet1/2-positive subpopulation with the duration of treatment. A minimum of 1000 DAPI-stained cells were counted in at least three different retinal preparations per treatment. The percentage of apoptotic cells among the Islet1/2-positive cells was determined in the same preparations but scoring all the individual Islet1/ 2-positive cells. Values in $(A, B)$ represent the mean \pm s.d. ${ }^{*}, \mathrm{P}<0.005$ for each experimental pair, calculated by Student's t-test. Reproduced from Díaz et al., 2000 with permission. () 2000 The Company of Biologists. 
TABLE 9

\section{REGULATION OF NEUROTROPHIC CELL DEATH IN THE GANGLION CELL LAYER}

\begin{tabular}{|c|c|c|c|}
\hline Molecule / experimental approach & Cell death phenotype & Retinal phenotype & References \\
\hline \multicolumn{4}{|l|}{ Bax } \\
\hline KO mouse. & $\begin{array}{l}\text { Apoptotic cells decrease } 98 \% \text { at } \mathrm{P} 2 \text { and } \mathrm{P} 7 \text { and } \\
94 \% \text { at } \mathrm{P} 15 \text {. }\end{array}$ & $\begin{array}{l}\text { GCL thicker from P2. Cells in the GCL and optic fibers increase } \\
50 \% \text {. RGC axons increase } 226 \% \text { in adults. }\end{array}$ & $\begin{array}{l}\text { Mosinger Ogilvie et al., } 1998 \\
\text { Péquignot et al., } 2003\end{array}$ \\
\hline \multicolumn{4}{|l|}{$\mathrm{Bcl}-2$} \\
\hline $\begin{array}{l}\text { Overexpressing transgenic mouse (NSE } \\
\text { promoter) }\end{array}$ & Apoptotic cells decrease $90 \%$ at $\mathrm{P} 2$. & $\begin{array}{l}\text { No modification in the number of RGCs between P2 and } \\
\text { adulthood. RGCs increase } 50 \% \text { in adults. }\end{array}$ & $\begin{array}{l}\text { Bonfanti et al., } 1996 \\
\text { Strettoi and Volpini, } 2002\end{array}$ \\
\hline $\begin{array}{l}\text { BDNF } \\
\text { BDNF }^{-/ /} \mathrm{NT}^{-/ /} \text {KO mouse. } \\
\text { BDNF }^{-/+} \mathrm{NT4}^{+/ /} \mathrm{KO} \text { mouse. }\end{array}$ & $\begin{array}{l}\text { Apoptotic RGCs increase } 1.7 \text { fold at P2. } \\
\text { Apoptotic RGCs increase } 1.4 \text { fold at P2. }\end{array}$ & Delayed retinal development. & $\begin{array}{l}\text { Pollock et al., } 2003 \\
\text { Harada et al., } 2006\end{array}$ \\
\hline $\begin{array}{l}\text { FasL } \\
\text { Gld (fas/ KO mouse). }\end{array}$ & $\begin{array}{l}\text { Apoptotic cells decrease } 72 \% \text { in the GCL at P2, } \\
\text { and } 81 \% \text { at } \mathrm{P} 15 \text {. }\end{array}$ & No altered phenotype in adult. & Péquignot et al., 2003 \\
\hline \multicolumn{4}{|l|}{$\mathbf{R b}$} \\
\hline KO mouse. & $\begin{array}{l}\text { Caspase- } 3 \text { activity increase } 90 \% \text { in the GCL at } \\
\text { E18.5. }\end{array}$ & Ectopic proliferating cells in the GCL at E18.5. & McPherson et al., 2004 \\
\hline $\begin{array}{l}\text { KO mouse (lox-nestin promoter } X \text { cre-pax } 6 \\
\text { promoter; deletion starts at E10). }\end{array}$ & $\begin{array}{l}\text { Caspase- } 3 \text { activity increase } 90 \% \text { in the GCL at } \\
\text { E18.5. }\end{array}$ & RGCs decrease $90 \%$ in 3 week- old mice. & \\
\hline \multicolumn{4}{|c|}{ ( } \\
\hline KO mouse. & $\begin{array}{l}\text { Apoptotic cells increase 4-fold from E18.5 to P3, } \\
\text { and 2-fold at P7. No modification in the number of } \\
\text { apoptotic cells from P9 to P14. }\end{array}$ & $\begin{array}{l}\text { 1.3-fold increase in the thickness of the GCL at P0. } \\
\text { Decrease in thickness of the GCL at P14 and in thickness of all } \\
\text { retinal layer at P28. }\end{array}$ & Miyawaki et al., 2004 \\
\hline \multicolumn{4}{|l|}{ TrkB } \\
\hline KO mouse. & Apoptotic RGCs increase 2-fold at P2 and P6. & No modification in the number of RGC axons in adult mice. & Pollock et al., 2003 \\
\hline
\end{tabular}

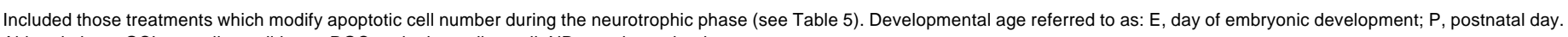
Abbreviations: GCL, ganglion cell layer; RGC, retinal ganglion cell; ND, not determined.

TABLE 10

\section{REGULATION OF NEUROTROPHIC CELL DEATH IN THE INNER AND OUTER NUCLEAR LAYERS}

\begin{tabular}{l} 
Molecule / experimental approach \\
\hline TrkB \\
Overexpression in chick embryos by retrovition of trunckated TrkB at E2.5. \\
infection \\
KO mouse. \\
Treatment of newborn rats (P0-7) with \\
antisense oligonucleotides. \\
Bax \\
KO mouse.
\end{tabular}

KO mouse.

Overexpressing transgenic mouse (rod-opsin promoter).

Bax \& Bak

Double KO mouse.

Bcl-2

Overexpressing transgenic mouse (NSE

promoter)

Bhlbh4

KO mouse.

BMPr1b

KO mouse.

FasL

Gld (fasl KO mouse).

IRS-2

KO mouse.

$\mathbf{R b}$

KO mouse.

KO mouse (lox-nestin promoter $\mathrm{X}$ cre-pax 6 promoter; deletion starts at E10).

Tlx

KO mouse.

\section{Cell death phenotype}

Increased apoptosis at E10-14.

(n)

Apoptotic cells decrease $83 \%$ in the INL at P7 and $\mathrm{P} 9$, and $72 \%$ in the ONL at P15.

Apoptotic PhR increase in the ONL at P11.

Apoptotic cells decrease in the INL at P7 and P9.

Decreased apoptosis.

Caspase- $3^{+}$cells increase from P8 (45\%) to P10 $(32 \%)$.

Apoptotic cells increase in the INL at P7.

Apoptotic cells decrease $60 \%$ in the ONL at P15.

Apoptotic cells increase $200 \%$ at $\mathrm{P} 7,60 \%$ at $\mathrm{P} 14$, normal values at P21. Caspase-3 activity increased in 9 week-old mice.

Apoptotic cells increase in the INL/ONL at P3.

Apoptotic cells increase in the INL and the ONL at P12.

Apoptotic cells increase 3 fold in the INL at P7 and $\mathrm{P} 9$. No modification in the number of apoptotic cells at P14.
Cellular phenotype

Cells in the INL increase $23 \%$ (likely AC). PhR number decreases $41 \%$ al E15.

Slight reduction of $\mathrm{AC}$ and lack of OFF-cone BC. Delayed PhR morphological differentiation.

Parvalvumin-expressing AC at P10-15 decrease 56\%.

Cells in INL increase $50 \%$. Cells in the ONL increase $75 \%$ in adults.

Reduced thickness of the ONL at P11. PhR number decreases 9-fold at P30.

Cells in the INL increase $50 \%$ in adults. Ectopic rods in the INL.

Cells in the INL increase in adults: BC, 50\%; AC, 10-fold; HC, $19 \%$.

Thickness of the INL decreases $21 \%$ in adults. Rod BC number decreases $64 \%$ at $\mathrm{P} 8$ and $92 \%$ at $\mathrm{P} 12$.

$\mathrm{BC}$ number decreases

No altered phenotype in adult.

PhR numbers decrease $10 \%$ at $\mathrm{P} 7,50 \%$ at $\mathrm{P} 14,50 \%$ in adult mice.

INL disorganization and ectopic cells in OPL in adults. PhR numbers decrease $50 \%$ in 3 week-old, 4 month-old and adult mice.

Slight reduction of $A C$ and lack of $B C$ at P12. Loss of

Slight reduction of $A C$ and lack of $B C$ at P12. Loss of
lamination in the INL and decrease of PhR number in 3 week-old mice.

1.3-fold increase in the thickness of the INL at P7.
Decrease in thickness of the INL at P14 and in thickness of all retinal layer at P28.
of
References

Rickman and Rickman, 1996 Rohrer et al., 1999 Turner et al., 2006

Mosinger- Ogilvie et al., 1998 Eversole-Cire et al., 2002 Péquignot et al., 2003

Hahn et al., 2003

Strettoi and Volpini, 2002

Bramblett et al., 2004

Li et al., 2003

Péquignot et al., 2003

Yi et al., 2005

McPherson et al., 2004

Miyawaki et al., 2004

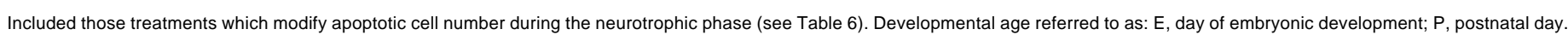
Abbreviations: AC, amacrine cells; BC, bipolar cells; INL: inner nuclear layer; ONL, outer nuclear layer; PhR, photoreceptor. 
Rosa, 2005). We encourage more detailed studies of retinal development to address the more complex involvement of cell death in retinal development as probably also occurs in the central nervous system as a whole.

\section{Acknowledgements}

We thank present and past members of the lab for their work in this project, Ms. Ana Robles for editing assistance, Dr. Violeta Gómez-Vicente for critical reading, and Prof. Flora de Pablo for continuous encouragement and ideas. Research in our group is supported by grants from Ministerio de Educación y Ciencia (SAF2007-66175 to EJdIR and BFU2006-00508 to $P B$ ) and from Comunidad de Madrid (CCG06-CSIC/SAL-0821 to PB). PB is a Ramón y Cajal Fellow.

\section{References}

ADLER, R. (2005). Challenges in the study of neuronal differentiation: a view from the embryonic eye. Dev. Dyn. 234: 454-463.

BABB, S.G., KOTRADI, S.M., SHAH, B., CHIAPPINI-WILLIAMSON, C., BELL, L.N., SCHMEISER, G., CHEN, E., LIU, Q. and MARRS J.A. (2005). Zebrafish Rcadherin (Cdh4) controls visual system development and differentiation. Dev. Dyn. 233: 930-945.

BEAZLEY, L.D., DUNLOP, S.A.,-HARMAN, A.M., and COLEMAN, L.A. (1988). Development of cell density gradients in the retinal ganglion cell layer of marsupials. Aust. Paediatr. J. 24 Suppl 1: 43-47.

BIEHLMAIER, O., NEUHAUSS, S.C. and KOHLER, K. (2001). Onset and time course of apoptosis in the developing zebrafish retina. Cell Tissue Res. 306: 199-207.

BONFANTI, L., STRETTOI, E., CHIERZI, S., CENNI, M.C., LIU, X.H., MARTíNOU, J.C., MAFFEI, L. and RABACCHI S.A. (1996). Protection of retinal ganglion cells from natural and axotomy-induced cell death in neonatal transgenic mice overexpressing bcl-2. J. Neurosci. 16: 4186-4194.

BOYA P. and DE LA ROSA E. J. (2005). Cell death in early neural life. Birth Defects Res. C Embryo Today 75: 281-293.

BRAEKEVELT C.R., BEAZLEY L.D., DUNLOP S.A., DARBY J.E. (1986). Numbers of axons in the optic nerve and of retinal ganglion cells during development in the marsupial Setonix brachyurus. Brain Res. 390: 117-125.

BRAMBLETT, D.E., PENNESI, M.E., WU, S.M., and TSAI, M.J. (2004). The transcription factor bhlhb4 is required for rod bipolar cell maturation. Neuron 43: 779-793.

BURRILL J.D. and EASTER, S.S. (1994). Development of the retinofugal projections in the embryonic and larval zebrafish (Brachydanio rerio). J. Comp. Neurol. 346: 583-600.

BUSS, R.R., SUN, W. and OPPENHEIM R.W. (2006). Adaptive roles of programmed cell death during nervous system development. Annu. Rev. Neurosci. 29: 1-35.

CANDAL, E., ANADÓN, R., DEGRIP, W.J. and RODRíGUEZ-MOLDES, I. (2005). Patterns of cell proliferation and cell death in the developing retina and optic tectum of the brown trout. Brain Res. Dev. Brain Res. 154: 101-119.

CECCONI, F., ÁLVAREZ-BOLADO, G., MEYER, B.I., ROTH, K.A. and GRUSS P. (1998). Apaf1 (CED-4 Homolog) Regulates Programmed Cell Death in Mammalian Dev. Cel/94: 727-737.

CELLERINO, A., BÄHR, M., and ISENMANN, S. (2000). Apoptosis in the developing visual system. Cell Tissue Res. 301: 53-69.

CEPKO, C.L., AUSTIN, C.P., YANG, X., ALEXIADES, M., and EZZEDDINE, D. (1996). Cell fate determination in the vertebrate retina. Proc. Natl. Acad. Sci. U. S. A. 93: 589-595.

CHAVARRÍA, T., VALENCIANO, A.I., MAYORDOMO, R., EGEA, J., COMELLA, J.X., HALLBÖÖK, F., DE PABLO, F. and DE LA ROSA E.J. (2007). Differential, agedependent ERK and PI3K activation by insulin acting as a survival factor in early retinal development. Dev. Neurobiol. 67: 1777-1788.

CHOW, L.R. and LANG R.A. (2001). Early eye development in vertebrates. Annu Rev Cell Dev Biol. 17: 255-296.

COHEN-CORY S, LOM B. (2004). Neurotrophic regulation of retinal ganglion cell synaptic connectivity: from axons and dendrites to synapses. Int. J. Dev. Biol. 48: 947-956.

COLE, L.K. and ROSS, L.S. (2001). Apoptosis in the developing zebrafish embryo.
Dev. Biol. 240: 123-142.

COOK, B., PORTERA-CAILLIAU, C. and ADLER, R. (1998). Developmental neuronal death is not a universal phenomenon among cell types in the chick embryo retina. J. Comp. Neuro/396: 12-19.

CRABTREE, J.W. (1989). Prenatal development of retinocollicular projections in the rabbit: an HRP study. J. Comp. Neurol. 286.504-513.

CRABTREE JW. (1990). Prenatal development of retinogeniculate projections in the rabbit: an HRP study. J. Comp. Neurol. 299: 75-88.

CUADROS, M. A. and RíOS, A. (1988). Spatial and temporal correlation between early nerve fiber growth and neuroepithelial cell death in the chick embryo retina. Anat. Embryol. 178: 543-551.

CUCCHIARO J. and GUILLERY R.W. (1984). The development of the retinogeniculate pathways in normal and albino ferrets. Proc. R. Soc. Lond. B. Biol. Sci. 223: 141 164.

CUSATO, K., STAGG, S.B. and REESE, B.E. (2001). Two phases of increased cell death in the inner retina following early elimination of the ganglion cell population. J. Comp. Neurol. 439: 440-449.

DAVIES, A.M. (2003). Regulation of neuronal survival and death by extracellular signals during development. EMBO J. 22: 2537-2545.

DÍAZ, B., PIMENTEL, B., DE PABLO, F. and DE LA ROSA, E. J. (1999). Apoptotic cell death affecting proliferating neuroepithelial cells in the embryonic retina is prevented by insulin. Eur. J. Neurosci. 11: 1624-1632.

DÍAZ, B., SERNA, J., DE PABLO, F. and DE LA ROSA E. J. (2000). In vivo regulation of cell death by embryonic (pro)insulin and the insulin receptor during early retinal neurogenesis. Development 127: 1641-1649.

DREHER, B. and ROBINSON, S.R. (1988). Developmental of the retinofugal pathway in birds and mammals: evidence for a common "timetable". Brain Beh. Evol. 31 369-390.

DUNLOP, S.A. and BEAZLEY, L.D. (1987). Cell death in the developing retinal ganglion cell layer of the wallaby Setonix brachyurus. J. Comp. Neurol. 264: 14 23.

EVERSOLE-CIRE, P., CHEN, J. and SIMON, M.I. (2002). Bax is not the heterodimerization partner necessary for sustained anti-photoreceptor-cell-death activity of Bcl-2. Invest. Ophthalmol. Vis. Sci. 43: 1636-1644.

FARAH, M.H. (2006). Neurogenesis and cell death in the ganglion cell layer of vertebrate retina. Brain Res. Rev. 52: 264-274.

FRADE, JM., RODRÍGUEZ-TEBAR, A. AND BARDE, Y.A. (1996). Induction of cell death by endogenous nerve growth factor through its $p 75$ receptor. Nature. 383 : 166-168.

FRANCISCO-MORCILLO, J., HIDALGO-SÁNCHEZ, M. and MARTÍN-PARTIDO G. (2004). Spatial and temporal patterns of apoptosis during differentiation of the retina in the turtle. Anat. Embryol. Berl. 208: 289-299.

FRANCISCO-MORCILLO, J., HIDALGO-SÁNCHEZ, M. and MARTÍN-PARTIDO G. (2006). Spatial and temporal patterns of proliferation and differentiation in the developing turtle eye. Brain Res. 1103: 32-48.

GALLI-RESTA, L. and ENSINI, M. (1996). An intrinsic limit between genesis and death of individual neurons in the developing retinal ganglion cell layer. J. Neurosci. 16 : 2318-2324.

GAZE, R.M. and GRANT, P. (1992). Spatio-temporal patterns of retinal ganglion cell death during Xenopus development. J. Comp. Neurol. 315: 264-274.

GLÜCKSMANN, A. (1940). Development and differentiation of the tadpole eye. Brithish J. Opthalmol. 154-178.

GODEMENT, P, SALAÜN, J, and IMBERT, M. (1984). Prenatal and postnatal development of retinogeniculate and retinocollicular projections in the mouse. $J$. Comp. Neurol. 230: 552-575.

GUERIN, M.B., MCKERNAN, D.P., O'BRIEN, C.J. and COTTER, T.G. (2006). Retina ganglion cells: dying to survive. Int. J. Dev. Biol. 50: 665-674.

HAGEDORN, M., and FERNALD, R.D. (1992). Retinal growth and cell addition during embryogenesis in the teleost, Haplochromis burtoni. J. Comp. Neurol. 321: 193208.

HAHN P., LINDSTEN, T., YING, G.S. BENNETT, J., MILAM, A.H., THOMPSON, C.B. and DUNAIEF J.L. (2003). Proapoptotic bcl-2 family members, bax and bak, are essential for developmental photoreceptor apoptosis. Invest. Ophthalmol. Vis. Sci. 44: 3598-3605.

HAMBURGER, V. and HAMILTON, H.L. (1951). A series of normal stages in the 
development of the chick embryo. J. Morph., 88: 49-92.

HANEL, M.L. and HENSEY C. (2006). Eye and neural defects associated with loss of GDF6. BMC Dev. Biol. 6: 43.

HARADA, C., HARADA, T., NAKAMURA, K., SAKAI, Y., TANAKA, K. and PARADA L.F. (2006). Effect of p75NTR on the regulation of naturally occurring cell death and retinal ganglion cell number in the mouse. Dev. Bio/290: 57-65.

HARADA, T., HARADA, C. and PARADA, L.F. (2007). Molecular regulation of visual system development: more than meets eye. Genes Dev. 8: 960-976.

HARRIS, W.A. (1997). Cellular diversification in the vertebrate retina. Curr. Opin. Genet. Dev. 7: 651-658.

HENDERSON, Z., FINLAY, B.L., and WIKLER, K.C. (1988). Development of ganglion cell topography in ferret retina. J. Neurosci8: 1194-1205.

HENSEY, C. and GAUTIER, J. (1998). Programmed cell death during Xenopus development: a spatio-temporal analysis. Dev. Biol. 203: 36-48.

HERNÁNDEZ-SÁNCHEZ, C., MANSILLA, A., DE LA ROSA, E.J. and DE PABLO, F. (2006). Proinsulin in development: New roles for an ancient prohormone. Diabetologia. 49: 1142-1150.

HIDALGO-SÁNCHEZ, M., FRANCISCO-MORCILLO, J., NAVASCUÉS, J. and MARTÍN-PARTIDO, G. (2006). Developmental changes in the fibre population of the optic nerve follow an avian/mammalian-like pattern in the turtle Mauremys leprosa. Brain Res. 1113: 74-85.

HOKE, K.L. and FERNALD, R.D. (1998). Cell death precedes rod neurogenesis in embryonic teleost retinal development. Brain Res. Dev. Brain Res. 111: 143-146.

HORSBURGH, G.M. and SEFTON, A.J. (1987). Cellular degeneration and synaptogenesis in the developing retina of the rat. J. Comp. Neurol. 263:553-566.

IJIMA, N. and YOKOYAMA, T. (2007). Apoptosis in the Medaka Embryo in the Early Developmental Stage. Acta Histochem. Cytochem. 40: 1-7.

IWAMATSU, T. (1994). Stages of normal development in the medaka. Oryzias latipes. Zool. Sci. 11: 825-839.

JENKINS, S. and STRAZNICKY, C. (1986). Naturally occurring and induced ganglion cell death. A retinal whole-mount autoradiographic study in Xenopus. Anat. Embryol. Berl. 174: 59-66.

KARLSSON, M., MAYORDOMO, R., REICHARDT, L.F., CATSICAS, S., KARTEN, H.J. and HALLBÖÖK, F. (2001). Nerve growth factor is expressed by postmitotic avian retinal horizontal cells and supports their survival during development in an autocrine mode of action. Development 128: 471-479.

KUAN, C.Y., ROTH, K.A., FLAVELL, R.A. and RAKIC, P. (2000). Mechanisms of programmed cell death in the developing brain. Trends Neurosci. 23: 291-297.

KUIDA, K., ZHENG, T. S., N.A, S., KUAN, C., YANG, D., KARASUYAMA, H., RAKIC, P., and FLAVELL, R.A. (1996). Decreased apoptosis in the brain and premature lethality in CPP32-deficient mice. Nature 384: 368-372.

KUWABARA T., and WEIDMAN, T.A. (1974). Development of the prenatal rat retina. Invest. Ophthalmol. Vis. Sci. 13: 725-739.

LAMB, T.D., COLLIN, S.P., PUGH, E.N. Jr. (2007). Evolution of the vertebrate eye: opsins, photoreceptors, retina and eye cup. Nat. Rev. Neurosci. 8: 960-976.

LAEMLE, L. K., PUSZKARCZUK, M., and FEINBERG, R. N. (1999). Apoptosis in early ocular morphogenesis in the mouse. Brain. Res. Dev. Brain Res. 112: 129-133.

LANGFORD, C. and SEFTON, A.J. (1992). The relative time course of axonal loss from the optic nerve of the developing guinea pig is consistent with that of other mammals. Vis. Neurosci. 9: 555-564.

LEU, S.T., JACQUESA, S.A.L., WINGERDA, K.L., HIKITAA, S.T., TOLHURSTA, E.C., PRINGA, J.L., WISWELLA, D., KINNEYA, L., GOODMANA, N.L., JACKSONB, D.Y, CLEGGA, D.O. (2004). Integrin alpha4beta1 function is required for cell survival in developing retina. Dev. Biol. 276: 416-430.

LEVINE, E.M. and GREEN, E.S. (2004). Cell-intrinsic regulators of proliferation in vertebrate retinal progenitors. Semin. Cell Dev. Biol. 151: 63-74.

LI, M.O., SARKISIAN, M.R., MEHAL, W.Z., RAKIC, P. and FLAVELL, R.A. (2003). Phosphatidylserine receptor is required for clearance of apoptotic cells. Science 302: 1560-1563.

LI, Z., HU, M., OCHOCINSKA, M.J., JOSEPH, M.N. and EASTER, S.S. (2000). Modulation of cell proliferation in the embryonic retina of zebrafish (Danio rerio). Dev. Dyn. 219: 391-401.

LINDEN, D.C., GUILLERY, R.W. and CUCCHIARO, J. (1981). The dorsal lateral geniculate nucleus of the normal ferret and its postnatal development. J. Comp.
Neurol. 203: 189-211.

DE LUCCHINI, S., ORI, M., CREMISI, F., NARDINI, M. and NARDI, I. (2005). 5-HT2Bmediated serotonin signaling is required for eye morphogenesis in Xenopus. Mol. Cell. Neurosci. 29: 299-312.

MACPHERSON, D., SAGE, J., KIM, T., HO, D., MCLAUGHLIN, M.E. and JACKS T. (2004). Cell type-specific effects of $\mathrm{Rb}$ deletion in the murine retina. Genes Dev. 18: 1681-1694.

MANSOUR-ROBAEY, S. and PINGANAUD, G. (1996). Development of the retinotectal arborisation of the trout. Anat. Embryol. 194: 279-287.

MARÍN-TEVA, J.L., CUADROS, M.A, CALVENTE, R., ALMENDROS, A. and NAVASCUES, J. (1999). Naturally occurring cell death and migration of microglial precursors in the quail retina during normal development. J. Comp. Neurol. 412: 255-275.

MARQUARDT, T. and GRUSS, P. (2002). Generating neuronal diversity in the retina: one for nearly all. Trends Neurosci. 25: 32-38.

MARTÍN-PARTIDO, G., RODRÍGUEZ-GALLARDO L., ÁLVAREZ, I.S and NAVASCUES, J. (1988). Cell death in the ventral region of the neural retina during the early development of the chick embryo eye. Anat. Rec. 222: 272-281.

MASLIM, J., VALTER, K., EGENSPERGER, R., HOLLANDER, H., and STONE, J. (1997). Tissue oxygen during a critical developmental period controls the death and survival of photoreceptors. Invest. Ophthalmol. Vis. Sci. 38: 1667-1677.

MAYORDOMO, R., VALENCIANO, A.I., DELA ROSA, E.J. and HALBÖÖK, F. (2003). Generation of retinal ganglion cells is modulated by caspase-dependent programmed cell death. Eur. J. Neurosci. 18: 1744-1750.

DE MELO, J., DU, G., FONSECA, M., GILLESPIE L.A., TURK, W.J., RUBENSTEIN, J.L.R. and EISENSTAT, D.D. (2005). DIx1 and DIx2 function is necessary for terminal differentiation and survival of late-born retinal ganglion cells in the developing mouse retina. Development 132: 311-322.

MERVIN, K. and STONE, J. (2002). Developmental death of photoreceptors in the C57BL/6J mouse: Association with retinal function and self-protection. Exp. Eye Res. 75: 703-713.

MIYAWAKI, T., UEMURA, A., DEZAWA, M., YU, R.T., IDE, C, NISHIKAWA, S., HONDA, Y., TANABE, Y., and TANABE, T. (2004). TIx, an orphan nuclear receptor, regulates cell numbers and astrocyte development in the developing retina. J. Neurosci. 24: 8124-8134.

MORCILLO, J., MARTÍNEZ-MORALES, J.R., TROUSSE, F., FERMIN, Y., SOWDEN, J.C. and BOVOLENTA P. (2006). Proper patterning of the optic fissure requires the sequential activity of BMP7 and SHH. Development. 133: 3179-3190.

MOSINGER OGILVIE, J., DECKWERTH, T.L., KNUDSON, C.M. and KORSMEYER S.J. (1998). Suppression of developmental retinal cell death but not of photoreceptor degeneration in Bax-deficient mice. Invest. Ophthalmol. Vis. Sci. 39: 1713-1720.

NIEUWKOOP, P.D. and FABER, J. (1967). Normal Table of Xenopus laevis(Daudin). North Holland, Amsterdam.

OZEKI, H., OGURA, Y., HIRABAYASHI, Y., and SHIMADA, S. (2000). Apoptosis is associated with formation and persistence of the embryonic fissure. Current Eye Res. 20: 367-372.

PÉQUIGNOT, M. O., PROVOST, A. C., SALLE, S., TAUPIN, P., SAINTON, K. M., MARCHANT, D., MARTINOU, J. C., AMEISEN, J. C., JAIS, J. P., and ABITBOL M. (2003). Major role of $B A X$ in apoptosis during retinal development and in establishment of a functional postnatal retina. Dev. Dyn. 228: 231-238.

PERRY, V.H., HENDERSON, Z. and LINDEN, R. (1983) Postnatal changes in retinal ganglion and optic axon populations in the pigmented rat. J. Comp. Neurol. 219: 356-368.

PIMENTEL, B., SANZ, C., VARELA-NIETO, I., RAPP, U.R., DE PABLO, F. and DE LA ROSA, E.J.(2000). c-Raf regulates cell survival and retinal ganglion cell morphogenesis during neurogenesis. J. Neurosci. 20: 3254-3262.

POLLOCK, G.S., ROBICHON, R., BOYD, K.A., KERKEL, KA, KRAMER, M., LYLES, J., AMBALAVANAR, R., KHAN, A., KAPLAN, D.R., WILLIAMS, R.W. and FROST D.O. (2003). TrkB receptor signaling regulates developmental death dynamics, but not final number, of retinal ganglion cells. J. Neurosci. 23: 10137-10145.

PORTERA-CAILLIAU, C., SUNG, C.H., NATHANS, J. and ADLER, R. (1994). Apoptotic photoreceptor cell death in mouse models of retinitis pigmentosa.-Proc Natl. Acad. Sci. U.S.A. 91: 974-978.

POTTS, R.A., DREHER, B. and BENNETT, M.R. (1982). The loss of ganglion cells in the developing retina of the rat. Brain Res. 255: 481-486. 
PRADA, C., PUGA, J., PÉREZ-MÉNDEZ, L., LOPEZ, R. and RAMÍREZ, G. (1991). Spatial and temporal patterns of neurogenesis in the chick retina. Eur. J. Neurosci. 3: 559-569.

PRESSON, J.C. and FERNALD, R.D. (1986). Development of the optic tract in the cichlid fish Haplochromis burtoni. Brain Res. 391: 179-186.

PROVIS, J.M. and VAN DRIEL, D. (1985). Retinal development in humans: the roles of differential growth rates, cell migration and naturally occurring cell death. Aust. N. Z. J. Ophthalmol. 13: 125-133.

PROVIS, J.M., VAN DRIEL, D., BILLSON, F.A., and RUSSELL, P. (1985a). Development of the human retina, patterns of cell distribution and redistribution in the ganglion cell layer. J. Comp. Neurol. 233: 429-451.

PROVIS, J.M., VAN DRIEL, D., BILLSON, F.A., and RUSSELL, P. (1985b). Human fetal optic nerve: overproduction and elimination of retinal axons during development J. Comp. Neurol. 238: 92-100.

PROVIS, J.M. (1987). Patterns of cell death in the ganglion cell layer of the human fetal retina. J. Comp. Neurol. 259: 237-246.

RADICK, P. and RILEY, K.P. (1983).Overproduction and elimination of retinal axons in the fetal rhesus monkey. Science 219: 1441-1444.

RAGER, G. and RAGER, U. (1979). Systems-matching by degeneration in the developing retino-tectal projection of the chicken. Prog Brain Res 51: 439-443.

REESE, B.E., THOMPSON, W.F. and PEDUZZI, J.D. (1994) Birthdates of neurons in the retinal ganglion cell layer of the ferret. J. Comp. Neuro/341: 464-475.

REESE B.E., JOHNSON PT, and BAKER GE. (1996). Maturational gradients in the retina of the ferret. J. Comp. Neurol.375: 252-73.

RICKMAN, D.W. and RICKMAN, B.C. (1996). Suppression of trkB expression by antisense oligonucleotides alters a neuronal phenotype in the rod pathway of the developing rat retina. Proc. Natl. Acad. Sci. U. S. A. 93: 12564-12569.

ROBINSON, S.R., HORSBURGH, G.M., DREHER, B. and MCCALL, M.J. (1987). Changes in the numbers of retinal ganglion cells and optic nerve axons in the developing albino rabbit. Brain Res. 432(2): 161-74

ROBINSON, S.R. (1988). Cell death in the inner and outer nuclear layers of the developing cat retina. J. Comp. Neurol. 267: 507-515.

RODRÍGUEZ-GALLARDO, L., LINEROS-DOMÍNGUEZ, M.C., FRANCISCOMORCILLO, J. and MARTÍN-PARTIDO, G. (2005). Macrophages during retina and optic nerve development in the mouse embryo: relationship to cell death and optic fibres. Anat. Embryol. 210: 303-316.

ROHRER, B., KORENBROT, J.I., LAVAIL, K.R. and REICHARDT, L.F. (1999). Role of neurotrophin receptor TrkB in the maturation of rod photoreceptors and establishment of synaptic transmission to the inner retina. J. Neurosci. 19: 89198930.

DE LA ROSA, E. J. and DE PABLO, F. (2000). Cell death in early neural development: beyond the neurotrophic theory. Trends Neurosci. 23: 454-458.

ROTH, K.A. andÄD'SA, C. (2001) Apoptosis and brain development. Ment. Retard Dev. Disabil. Res. Rev. 7: 261-266.

SANDERS, E.J., PARKER, E., ARÁMBURO, C. and HARVEY, S. (2006). Retinal growth hormone is an anti-apoptotic factor in embryonic retinal ganglion cell differentiation. Exp. Eye Res. 81: 551-560.

SATO, N., SAKUMA, C., SATO, Y., GOULD, T.W., OPPENHEIM, R.W., and YAGINUMA, H. (2006). Distinct susceptibility of developing neurons to death following Bax overexpression in the chicken embryo. Cell Death Diff. 13: 435-445.

SCHMITT, E.A. and DOWLING, J.E. (1994). Early eye morphogenesis in the zebrafish, Brachydanio rerio. J. Comp. Neurol. 344: 532-542.

SCHMITT, E.A. and DOWLING, J.E. (1996). Comparison of topographical patterns of ganglion and photoreceptor cell differentiation in the retina of the zebrafish, Danio rerio. J. Comp. Neurol. 371: 222-234.

SCHMITT, E.A. and DOWLING, J.E. (1999). Early retinal development in the zebrafish, Danio rerio: light and electron microscopic analyses. J. Comp. Neurol. 404: $515-536$

SENGELAUB, D.R. and FINLAY, B.L. (1982). Cell death in the mammalian visual system during normal development : I. Retinal ganglion cells. J. Comp. Neurol. 204: $311-317$
SENGELAUB, D.R., DOLAN, R.P. and FINLAY, B.L. (1986). Cell generation, death, and retinal growth in the development of the hamster retinal ganglion cell layer. $J$ Comp Neurol. 246: 527-543.

SENUT, M.C. and ALVARADO-MALLART, R.M. (1986). Development of the retinotectal system in normal quail embryos: cytoarchitectonic development and optic fiber innervation. Dev. Brain Res 29: 123-140.

SPIRA, A., HUDY, S. and HANNA, R. (1984) Ectopic photoreceptor cells and cell death in the developing rat retina. Anat. Embryol. Berl. 169: 293-301.

STRETTOI, E. and VOLPINI, M. (2002). Retinal organization in the bcl-2-overexpressing transgenic mouse.'J. Comp. Neurol. 446: 1-10.

STRONGIN, A.C. and GUILLERY, W. (1981). The distribution of melanin in the developing optic cup and stalk and its relation to cellular degeneration. J. NeurosCi. 1: 1193-1204.

STURROCK, RR. (1987). Changes in the number of axons in the human embryonic optic nerve from 8 to 18 weeks gestation J. Hirnforsch. 28: 649-652.

TROUSSE, F., ESTEVE, P. and BOVOLENTA, P. (2001). BMP4 mediates apoptotic cell death in the developing chick eye. J. Neurosci21: 1292-1301.

TURNER, B.A., SPARROW, J., CAI, B., MONROE, J., MIKAWA, T. and HEMPSTEAD, B.L. (2006). TrkB/BDNF signaling regulates photoreceptor progenitor cell fate decisions. Dev. Biol. 299: 455-465.

VALENCIANO, A.I., MAYORDOMO, R., DE LA ROSA, E.J. and HALLBÖÖK, F (2002). Biotin decreases retinal apoptosis and induces eye malformations in the early chick embryo. Neuroreport. 13: 297-299.

VAN KLEFFENS, M., GROFFEN, C., NECK J.W., VERMEIJ-KEERS, C and DROP S.L. (1999). mRNA and protein localization of the IGF system during mouse embryonic development in areas with apoptosis. Growth Horm. IGF Res. 9: 195204.

VECINO, E., HERNÁNDEZ, M. and GARCÍA, M. (2004). Cell death in the developing vertebrate retina. Int. J. Dev. Biol. 48: 965-974.

VOGEL, M. and MÖLLER, K. (1980). Cellular decay in the rat retina during normal post-natal development: a preliminary quantitative analysis of the basic endogenous rhythm. Albrecht Von Graefes Arch. Klin. Exp. Ophthalmol. 212: 243-260.

WALSH, C, POLLEY, E.H, HICKEY, T.L. and GUILLERY, R.W. (1983). Generation of cat retinal ganglion cells in relation to central pathways. Nature. 302: 611-614.

WILLIAMS, M.A., PIÑON, L.G.P., LINDEN, R. and PINTO, L.H. (1990). The pear mutation accelerates the schedule of natural cell death in the early post-nata retina. Exp. Brain Res 82: 393-400.

WILLIAMS, R.W, BASTIANI, M.J., LIA, B. and CHALUPA, L.M. (1986). Growth cones, dying axons, and developmental fluctuations in the fiber population of the cat's optic nerve. J. Comp. Neurol. 246: 32-69.

WONG, R.O. and HUGHES, A. (1987). Role of cell death in the topogenesis of neuronal distributions in the developing cat retinal ganglion cell layer. J. Comp. Neurol. 262: 496-511.

WU L.Y., LI, M., HINTON, D.R., GUO, L., JIANG, S., WANG, J.T., ZENG, A., XIE, J.B., SNEAD, M., SHULER, C., MAXSON R.E., AND LIU, Y.H. (2003). Microphthalmia resulting from MSX2-induced apoptosis in the optic vesicle. Invest. Ophthalmol. Vis. Sci. 44: 2404-2412.

YEO, W. and GAUTIER, J. (2004) Early neural cell death: dying to become neurons. Dev. Biol. 274, 233-244.

YI, X., SCHUBERT, M., PEACHEY, N.S., SUZUMA, K. BURKS, D.J., KUSHNER, J.A., SUZUMA, I., CAHILL, C., FLINT, C.L., DOW, M.A., LESHAN, R.L., KING J.L. and WHITE, M.F. (2005). Insulin receptor substrate 2 is essential for maturation and survival of photoreceptor cells. J. Neurosci. 25: 1240-1248.

YODA, H., HIROSE, Y.,nYASUOKA, A., SASADO, T., MORINAGA, C., DEGUCHI, T., HENRICH, T., IWANAMI, N., WATANABE, T., OSAKADA, M., KUNIMATSU, S., WITTBRODT, J., SUWA, H., NIWA, K., OKAMOTO, Y., YAMANAKA, T., KONDO, H.H. and FURUTANI-SEIKI, M. (2004). Mutations affecting retinotectal axonal pathfinding in Medaka, Oryzias latipes. Mech. Dev. 121: 715-728.

YOUNG, R.W. (1984) Cell death during differentiation of the retina in the mouse. $J$ Comp. Neurol. 229: 362-373. 


\section{Related, previously published Int. J. Dev. Biol. articles}

See our recent Special Issue Ear Development edited by Bernd Fritzsch and Fernando Giraldez at: http://www.ijdb.ehu.es/web/contents.php?vol=51\&issue=6-7

See our Special Issue Eye Development edited by Joram Piatigorsky and Robert Grainger at: http://www.ijdb.ehu.es/web/contents.php?vol=48\&issue=8-9

Drosophila retinal pigment cell death is regulated in a position-dependent manner by a cell memory gene Nicolas Dos-Santos, Thomas Rubin, Fabienne Chalvet, Pierre Gandille, Frederic Cremazy, Jacqueline Leroy, E. Boissonneau and Laurent Théodore

Int. J. Dev. Biol. (2008) 52: 21-31

Expression and regulation of Xenopus CRMP-4 in the developing nervous system Jacob Souopgui, Tiemo J. Klisch, Tomas Pieler and Kristine A. Henningfeld Int. J. Dev. Biol. (2007) 51: 339-343

The Xenopus ortholog of the nuclear hormone receptor Nr2e3 is primarily expressed in developing photoreceptors

Reyna I. Martinez-De Luna and Heithem M. El-Hodiri

Int. J. Dev. Biol. (2007) 51: 235-240

Retinoic acid is required for specification of the ventral eye field and for Rathke's pouch in the avian embryo

Malcolm Maden, Aida Blentic, Susan Reijntjes, Sophie Seguin, Emily Gale and Anthony Graham

Int. J. Dev. Biol. (2007) 51: 191-200

Expression of Bmp ligands and receptors in the developing Xenopus retina Jennifer C. Hocking and Sarah McFarlane

Int. J. Dev. Biol. (2007) 51: 161-165

NMDA-receptor blockade enhances cell apoptosis in the developing retina of the postnatal rat

María Hernández, Inmaculada Guerrikagoitia, Luis Martínez-Millan and Elena Vecino Int. J. Dev. Biol. (2007) 51: 117-122

Key apoptosis regulating proteins are down-regulated during postnatal tissue development

Shane D. Madden, Maryanne Donovan and Thomas G. Cotter

Int. J. Dev. Biol. (2007) 51: 415-424

Proliferation and apoptosis in early molar morphogenesis - voles as models in odontogenesis

Jana Setkova, Herve Lesot, Eva Matalova, Kirsti Witter, Petra Matulova and Ivan Misek Int. J. Dev. Biol. (2006) 50: 481-489

Retinal ganglion cells: dying to survive

Marc B. Guerin, Declan P. McKernan, Colm J. O'Brien and Thomas G. Cotter Int. J. Dev. Biol. (2006) 50: 665-674

Cell death in the developing vertebrate retina Elena Vecino, María Hernández and Mónica García Int. J. Dev. Biol. (2004) 48: 965-974

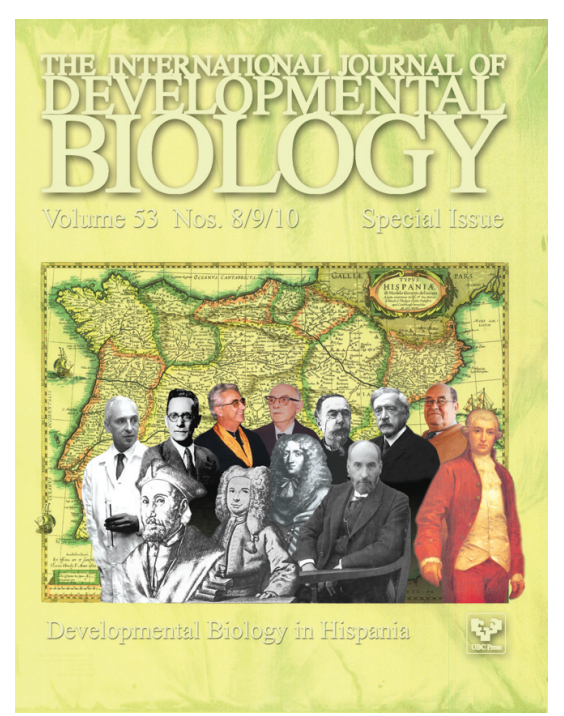

5 yr ISI Impact Factor $(2008)=3.271$

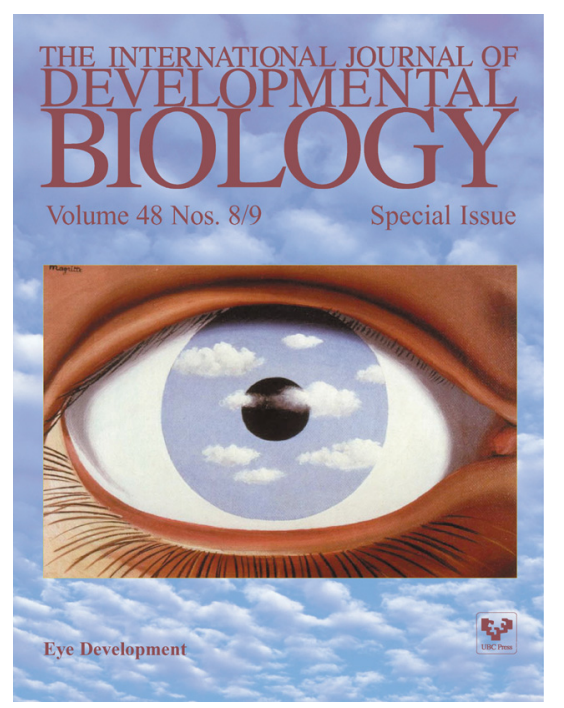

